Historic, archived document

Do not assume content reflects current scientific knowledge, policies, or practices. 



\subsection{3}

THOMAS MEEHAN

THOMAS B. MEEHAN

J. FRANK TEEHAN

S. MENDELSON MEEHAN

\section{Fall of 1894}

\section{MeEhans' 75 acres

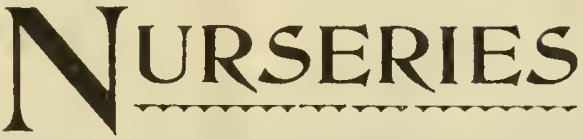

\section{WHOLESALE TRADE LIST}

\section{THOMAS MIEEHAN \& SONS}

ESTABLISHED 1852

GERMANTOWN, PHILADELPHIA, PA.

\section{Notice TO CUSTOMERS}

In ordering stock sent by mail, add ten cents on every dollar for Deciduous Trees, and fifteen cents for Evergreens, to prepay postage. For Seeds, ten cents per pound.

Parties are requested to state the mode of conveyance by which they desire their trees forwarded. When no route is named we forward to the best of our judgement; but in no case do we assume any responsibility after the goods are shipped, unless for our own mistake.

TERMS, in all cases, cash, on or before delivery to express or railroad agents, unless by special arrangement.

Five hundred, fifty, and five, will be furnished at the thousand, hundred, and ten rates respectively. Packing Charged Extra.

Post Office Orders payable at Station G, Philadelphia.

Our Retail Catalogue is complete and will be sent to all applicants.

Visitors are always welcome, and should take train at i 2 th and Market Sts., Philadelphia, for Chestnut Hill, getting off at IVALNUT LANE STATION; - or at Broad and Filbert Streets, getting out at CARPENTER ST. STATIOx. Trains run every half hour, both ways. Cabs at both stations. The Eighth Street Flectric cars conie to within two squares of our Nurseries. I,eave cars at CHrRch St., Germaxtow. 


\section{ree Seedlings}

\section{for Nurserymen}

We have the largest stock of these in the United States, all of our own grown, and very much superior in every respect to foreign grown stock.

$\stackrel{\mathrm{ar}}{\mathrm{O}}$

Norraay, sycamore, Sugar and Red Maple Seedlings

we have an especially fine lot.

Also of RED-BUD or JUDAS,

WHITE DOGWOOD,

RED-FLOWERED DOGWOOD

WEEPING DOGWOOD,

BEECH, ASH,

BLACK WALNUT, TULIP TREE,

MAGNOLIA, MULBERRY,

PLANE Or EUROPEAN SYCAMORE,

POPLAR, OAKS IN VARIETY,

MAIDEN HAIR or GINGKO,

LINDEN and ELMS.

Of nearly all of the above we have large transplanted stock also, in the very best of health and condition.

\section{Our stock of \\ SHRUBS AND EVERGREENS}

is very large and in the most healthy and thrifty condition.

\section{NORעLAY SPRUCE.}

Of these we have a large stock of fine, shapely plants at low prices.

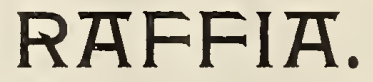

We are large importers of Raffia and can always supply it in quantities.

Prices (variable) on application. 


\section{Deciduous Trees.}

The letters (tr.) signify that the stock has been once or more transplanted, (S) that it is still in seedling beds.

\section{ACER POLYMORPHUM ATROPURPUREUM.}

Japan Blood-Leaved Maple.

Whe invite the attention of our customers to the very low prices at which we are offering these plants this year. We claim that they are superior to all others as we grow them on their owe roots. They grow better and hold a better color than grafted plants, and the vitality is greater. We now make them one of cur specialties, and grow a large supply yearly.

The color of the foliage is a rich crimson, and the plant frequently makes a second growth in the fall, the color of which is darker than at midsummer.

Prices, below.

\section{Acacia julibrissin,}

\section{Acer campestre, European Cork \\ " dasycarpum, Silver

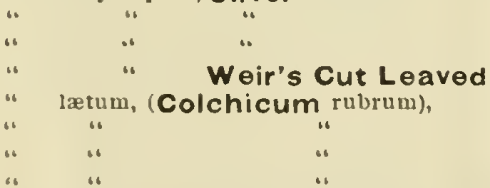

inacrophyllum, Oregon Maple. obtusatum,

platanoides, Norway "

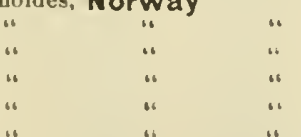

Reitenbachl, Schweidlerl,

polymorphum, Japan Maple, atropurpureum, Blood-leav'd

Japan Maple, 8 to $12 \mathrm{in}$. tr. busby 350 Blood-leav'd

Japan Maple, 12 to ls in. tr. bushy 400 Blood-leav'd

Japan Maple, 15 to 24 in. tr. busby 650

9 to $10 \mathrm{ft}$. tr. $\quad+00$

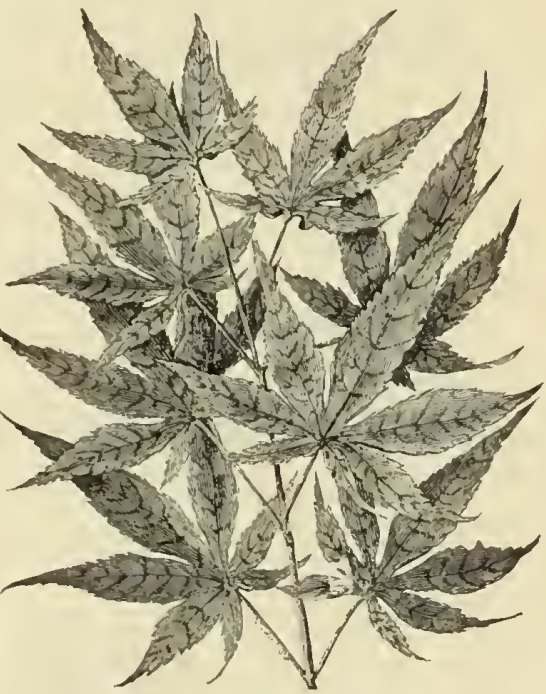

Per 10 Per 100 Per 1000

18 to $21 \mathrm{in.}$ tr. $\$ 150$

3 to $4 \mathrm{ft}, \mathrm{tr} . \quad 400$

Maple, 4 to $5 \mathrm{in.}$ \&. $\quad 35 \quad \$ 250$

3 to $4 \mathrm{ft} . \mathrm{S} . \quad 75 \quad 500$

" 12 to 18 iu. s. $35 \quad 75 \quad \$ 500$

" 3 to $5 \mathrm{ft}$. tr. 50

" 9 to $10 \mathrm{ft}$.tr. $200 \quad 1800$

“ 5 to $6 \mathrm{ft}$ tr. $\quad 30$ n

8 to 12 in. $\therefore$. $\quad 35$

18 to $24 \mathrm{wn}$. tr. 100

$3 \mathrm{ft}, \mathrm{tr} . \quad 150$

$8 \mathrm{ft}$. tr. $\quad 300$

12 to 18 in. S. $\quad 100$

5 to 6 ill. S. 50

5 iu. S. $\quad 25$

12 to 18 in. S. $\quad 50$

2 to $3 \mathrm{ft}$. S. $\quad 6.5$

4 to $5 \mathrm{ft} . \mathrm{S} . \quad 100$

6 to $8 \mathrm{ft} . \mathrm{tr} . \quad 250$

3 to $4 \mathrm{ft}$. $\mathrm{tr} . \quad 350$

4 to $5 \mathrm{ft} . \mathrm{tr} . \quad 500$

12 to $18 \mathrm{in}$. tr. 300 


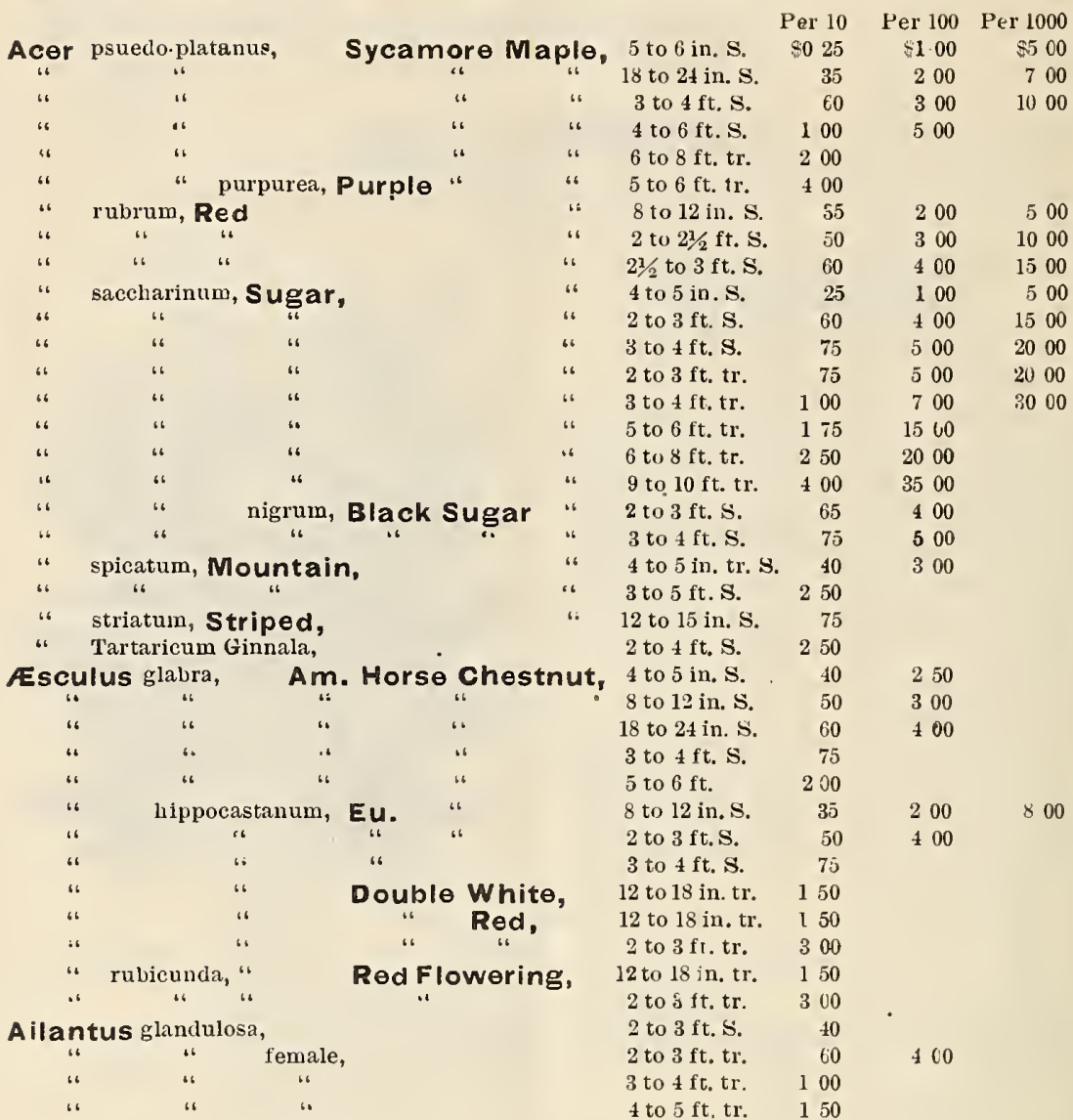

DEs The offensive odor of the flowers of the Ailat thus is not nearly as pronounced in the female plants. It is searcely perceptible.

Alder, see Alnus, below.

Alnus glutinosa, Eu. Alder,

6 in. $\mathrm{S}$.

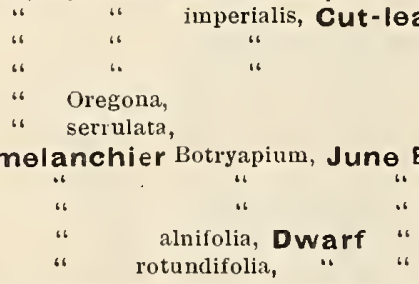

Amygdalus Persica, Double White Flowerlng

Andromeda arborea,

Anona triloba, Pawpaw,

Aralia spinosa
Peach, 3 to $4 \mathrm{ft}$.tr. 250

3 to 4 ft. tr. 250

12 to 18 in. tr. 350

18 to 24 in. S. 100

3 to $4 \mathrm{ft}$. S. $\quad 200$

5 to 6 in. S. $\quad 50$

2 to $3 \mathrm{ft}$. tr. $\quad 250$
800

300 
Aralia caneseens,

"Jiponica,

Ash, see Fraxinus, page 8 .

Beech, see Fagus, page 8.

Betula alba, Eu.

$$
\text { ". ". }
$$$$
\text { " }
$$$$
\text { 11 } 4
$$$$
\text { 16 } 11
$$$$
\text { ". }
$$$$
\text { lenta, Sweet }
$$$$
\text { ". " }
$$$$
\text { " " }
$$

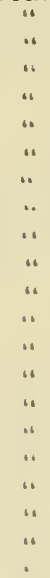$$
\text { "Leiniata, Cut-leaved Birch, }
$$$$
\text { lutea, Y ellow }
$$

Birch, see lietula, ahore.

$B \cdot r d$ Cherry, see Cerasus, page 7 .

Box Elder, see Negundo, page 10.

Bullernut, see Juglans, page 9.

Carpinus Americana, Am. Hornbeam, ".

$$
\text { “ Betulua, Eu. }
$$

Carya alba,

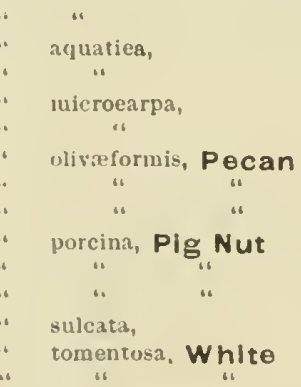

Castanea Americana,

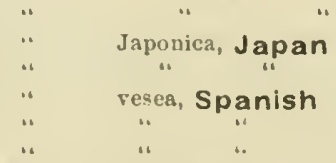

White Birch
".
".
Birch,
."
".
".
".
".
".

Per 10

12 to 18 in. tr. s 150 12 to 18 in. tr. 150 2 to $3 \mathrm{ft}$. tr. $\quad 250$

Per 100 Per 1000 12 to 18 in. $\mathrm{s}$. 35 18 to 21 in. $s$. $1 \mathrm{ft} . \mathrm{tr}$. 50 2 to $3 \mathrm{ft} . \mathrm{tr} . \quad 100$ $5 \mathrm{ft} . \mathrm{tr} . \quad 200$ $5 \mathrm{ft} . \mathrm{tr} . \quad 350$ 3 to 4 in. S. $\quad 35$ 12 to $18 \mathrm{in} . \mathrm{S}$. $\quad 50$ 18 to $24 \mathrm{in}, \mathrm{S}$. $\quad 60$ 3 to $4 \mathrm{in}$. S. $\quad 35$ 12 to 15 in. S. 50 3 to 4 ill. $8 . \quad 3.5$ 12 to 18 in. $\mathrm{s}$. 50 6 to $8 \mathrm{ft}$. tr. 250 3 to 4 in. S. 35 18 to 24 in. S. $\quad 60$ 18 to $2 t$ in. S. $\quad 350$ 6 to 8 in. S. $\quad 35$ $12: 018$ in. S. $\quad 50$ 2 to $3 \mathrm{ft} . \mathrm{S}$. 65 3 to $4 \mathrm{ft} . \mathrm{S}$. $\quad 75$
$\$ 150$

200

300

300

200

300

400

200

300

200

200

410

200

300

400
Am. Chestnut,

12 to $15 \mathrm{in.S.} \quad 50$ $2 \frac{1}{3}$ to $3 \mathrm{ft} . \mathrm{S} . \quad 100$ 3 to $4 \mathrm{ft}$. tr. 250 18 to 24 in. tr. $\quad 150$ 4 to 5 ft. tr. $\quad 300$ Shellbark Hickory, 3 to 5 in. S. $\quad 40$ 6 to 8 in. S. 75 12 to 38 in. S. 100 6 to 8 in. $\mathrm{s}$. $\quad 60$ 12 to 18 in. S. 75 3 to $5 \mathrm{in.}$ S. $\quad 40$ 19 to 24 in. S. 100 6 in. $\mathrm{s.} \quad 50 \quad 400$

8 to 12 ins. . $\quad 75 \quad 600$ 2 to $3 \mathrm{ft} . \mathrm{S} . \quad 200$ 3 to 5 in. S. $\quad 40 \quad 300$ 6 to 8 in. $5 . \quad 50$ 2 to $3 \mathrm{ft} . \mathrm{S} . \quad 125 \quad 800$ 6 to 8 in. S. $\quad 50$ 3 to 5 in. S. $\quad 40 \quad 250 \quad \varepsilon 1500$ 8 to 12 in. s. $60 \quad 400$ is 00 18 to 21 in. 8 . 100 4 to $5 \mathrm{ft}$. $\mathrm{s.} \quad 150$ 5 to $6 \mathrm{ft} . \mathrm{s} . \quad 200$ 8 to 12 in. S. $100 \quad 800$ 3 to $4 \mathrm{ft}$. S. $\quad 200$ 6 to 8 in. S. $\quad 50 \quad 300$ 12 to $18 \mathrm{ins} \mathrm{S}$. $6.5 \quad 500$ 18 to 21 in. S. $75 \quad 600$
2000

1000

300

45e Japan bears the largest nuts of all Clestnut tree ${ }^{2}$, fruiting when lut three or four feet high. The nuts are mucl larger than the Spanish, and of better quality. Trees but four to five years old frequently have nuts on them. 
Catalpa bignonioides,

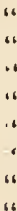

“

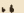

11

,

11

Celtis occidentalis, Nettle Tre日,

" pumila, Dwarf " "

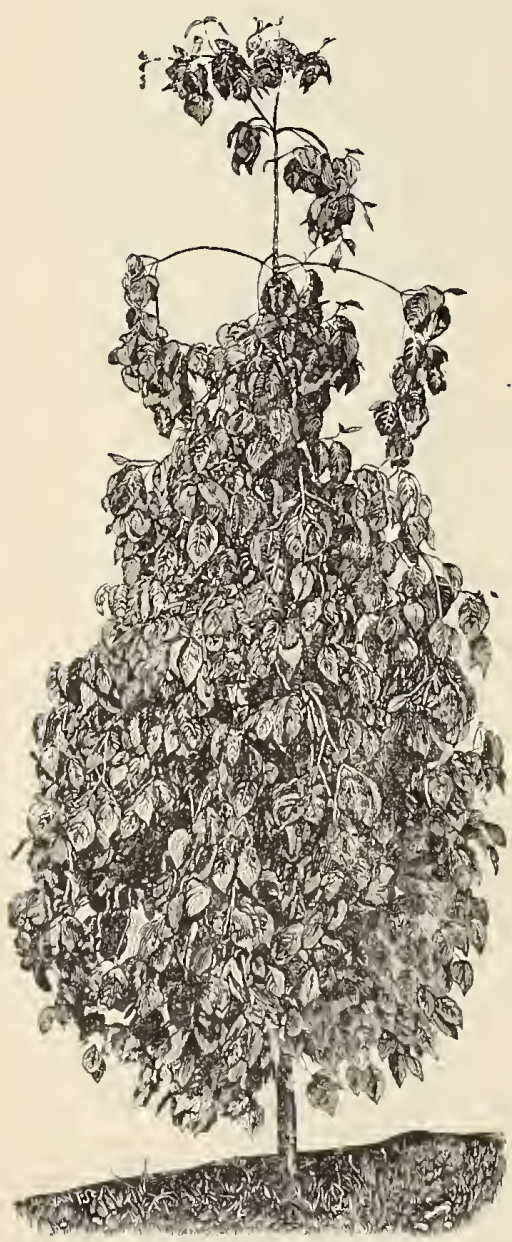

CORNUS FLORIDA PENDULA.

\begin{tabular}{|c|c|c|c|}
\hline & Per 10 & Per 100 & Per 1000 \\
\hline 12 to 18 in. $\mathrm{s}$. & $\leqslant 035$ & 8260 & \\
\hline 3 to $4 \mathrm{ft} . \mathrm{S}$. & 50 & 300 & \\
\hline 2 to $3 \mathrm{ft} . \mathrm{tr}$. & 300 & & \\
\hline 12 to 18 in. tr. & 250 & & \\
\hline 8 to 12 in. $\mathrm{S}$. & 50 & 350 & \\
\hline 18 to 24 in. S. & 75 & 500 & \\
\hline 7 to $9 \mathrm{ft} . \mathrm{tr}$. & 350 & & \\
\hline 12 to 18 in. $S$. & 35 & 200 & $\$ 600$ \\
\hline 2 to $3 \mathrm{ft} . \mathrm{S}$. & 50 & 300 & \\
\hline 3 to $4 \mathrm{ft}$. S. & 60 & 400 & \\
\hline 18 to 24 in. $\mathbf{s}$. & 65 & 500 & \\
\hline 2 to $3 \mathrm{ft} . \mathrm{S}$. & 75 & 600 & \\
\hline 12 to 18 in. 5. & 75 & 600 & \\
\hline 2 to $3 \mathrm{ft} . \mathrm{S}$. & $1 \mathrm{CO}$ & & \\
\hline
\end{tabular}

\section{WEEPING DOGWOOD.}

(Cornus Florida Pendula.)

Of all the weeping trees, there is none, to our mind, equal in beauty to this one. It is very hardy, and will thrive from Canada to Florida. As will be seen by the picture of a large specimen on our grı unds, the branches are very pendulous, but the leader shoots up as straight as an arrow.

It bears a great profusion of large white flowers in spring, followed by bright red berries in fall, just the same as the White Flowered sort.

After growing it for upwards of ten years we can recommend it as one of the finest ornamental weeping trees grown.

\section{WHITE FLOWERED DOGWOOD.}

(Cornus Florida.)

We believe that our stock of this beautiful ornamental tree is larger than can be found in any other establishment in the world. IVe have no less than 40,000 seedlings alone. It is one of our specialties. It always sells well, as it is a plant that we can recommend, its beauty at all seasons pleasing every one. For prices see page 7 . 


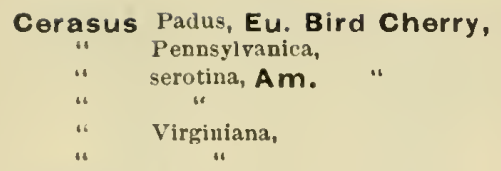

Cercis Canadensis, Am. Judas,

$\begin{array}{llll}" \text { " } & \text { " } & \text { " } & \text { " } \\ " & \text { Japonica, Japan } & \text { " } \\ " & \text { " } & \text { " } & \text { " }\end{array}$

Chestnul, see Castanea, page 5.

Cladastris tinctoria, Yellow Wood, Cornus florida, White flowered Do

\begin{tabular}{|c|c|c|}
\hline " & ". & “ \\
\hline " & ". & " \\
\hline " & "4 & " \\
\hline " & "4 & “ \\
\hline ". & $"$ & rubro, Red flowered \\
\hline “ & " & ." \\
\hline$"$ & $"$ & pendula, Weeping \\
\hline
\end{tabular}

Per 10

18 to $24 \mathrm{in.} \mathrm{S.} \$ 075$

12 to 18 in. S. $\quad 75$

18 to 24 in. $\mathrm{S}$. $\quad 50$

2 to $3 \mathrm{ft}$. S. $\quad 75$

2 to $3 \mathrm{ft}$. S. $\quad 75$

3 to $\mathrm{fft} . \mathrm{S} . \quad 100$

2 to $3 \mathrm{ft}$. S. $\quad 75$

3 to $1 \mathrm{ft}$. S. $\quad 100$

4 to $5 \mathrm{ft}$.tr. $\quad 175$

6 to $10 \mathrm{in.S.} \quad 50$

18 to $24 \mathrm{in.}$ S. 150

2 to $3 \mathrm{ft}$. S. $\quad 200$

Per 100 Per 1000

$\$ 300$

600

800

1500

300

1200

1500

$\$ 5000$

2000

8 to 12 in. S. $\quad 100$

6 to 8 in. 8 . 35

18 to 24 in. S. $\quad 50$

2 to $3 \mathrm{ft}$. S. $\quad 75$

3 to $4 \mathrm{ft}$. S. $\quad 100$

3 to 41 t. tr. 250

i to $5 \mathrm{ft}$. tr. $\quad 350$

$21 / 2$ to $3 \mathrm{ft}$. tr. 350

3 to $31 / 2$ ft. tr. $\& 50$

$21 / 2$ to $3 \mathrm{ft}$. tr. 350

3 to 4 ft.tr. $\quad+00$
$200 \quad 1200$

$350 \quad 1500$

500

600

2000

3000

3500

4500

3500

4000

\section{CORNUS FLORIDA FLORE RUBRO.}

\section{Red Flowered Dogwood.}

Ever since we commenced pushing this wost beautiful variety of Dog. wood, its sale has been unpreced. ented, and our stock has always run short long before the selling teason ended, thougl we werc growing it by the thousands. The deunand grew so rapidly that we resolved to say nothing commendatory of it in our wholesale ratalogue last fall or the following spring : notwithstauding this our stock was colupletely sold out. We think that we can trals say that no other tree or slirub took the popular fancy quicker than did tlis. Ilse flowers are not red, but a beautif ul deep pink. Last spring we sent a numlier of flowers to onr rctall custowers, three-fourth of the flow ers so sent bringing orders to us, not for one plant, but in many cases from three to six for one customer. For cemetery planting, there is no finer class of trees than the Cornus forila and its two beautiful varieties, C. f. rubro and C. f. pendula.

For prices see above.

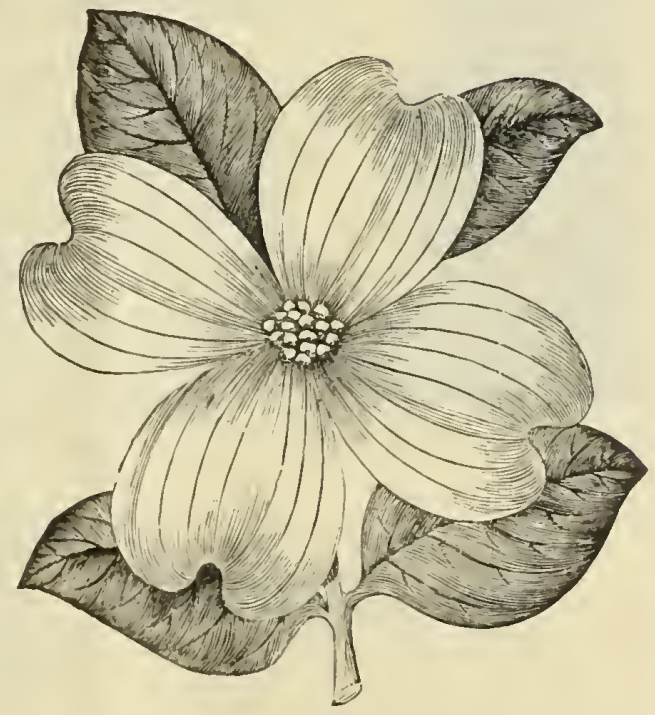

Cytisus Laburnum,

$\begin{array}{lrr}12 \text { to } 18 \text { in. S. } & 50 & 250 \\ 2 \text { to } 3 \mathrm{ft} . \mathrm{S} . & 75 & 500 \\ 3 \text { to } \mathrm{ft} . \mathrm{fs} . & 100 & 600 \\ & & \\ 12 \text { to } 18 \mathrm{ins} . \mathrm{tr} . & 200 & \\ 2 \text { to } 3 \mathrm{ft} . \mathrm{S} . & 75 & 500 \\ 3 \text { to } 4 \mathrm{ft.S.} & 100 & 800\end{array}$

$$
\text { " " " }
$$

Deciduous Cypress, see Taxodium, page 11.

\section{Dimorphanthus Mandslıuricus, \\ Diospyros Virginiaua, Persimmon,}

Dogw sod, sec Cornus above, also page 16 .

Elder, see Sidubucus, page 20

$E l m$, see Ulmus, page 14.

Empress Tree, see P'aulowila, page 10. 


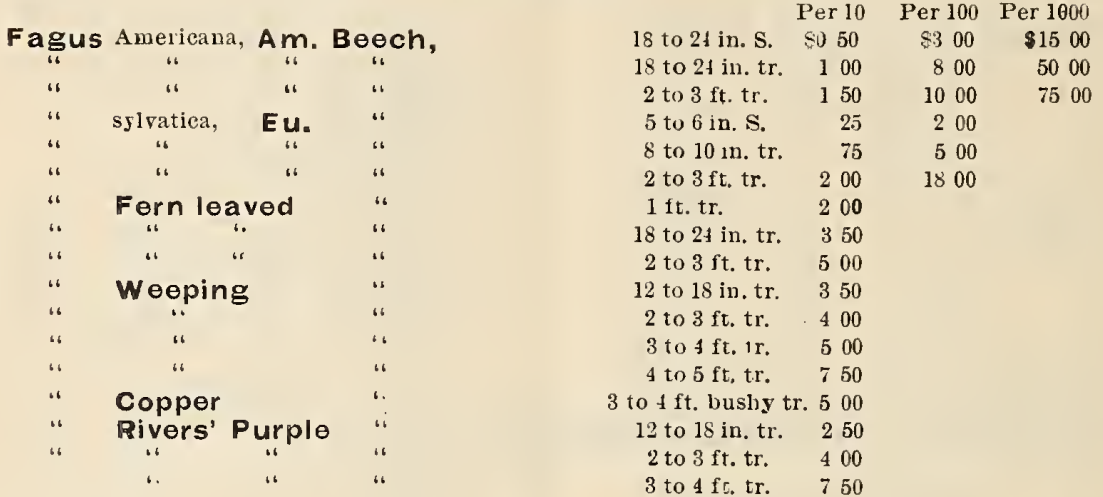

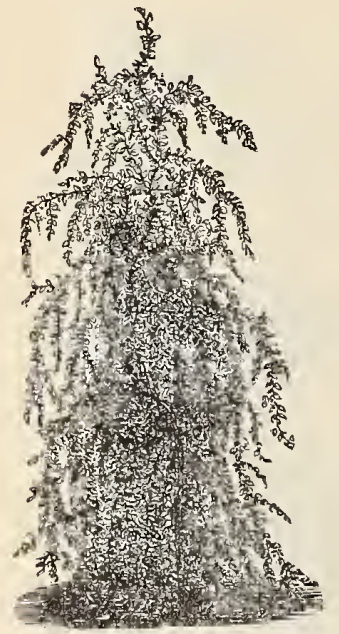

We have an exceptionally fine stock of the following Beeches :

\section{AMERICAN BEECH, EUROPEAN BEECH, RIVERS' PURPLE-LEAVED BEECH, FERN LEAVED BEECH, WEEPING BEECH,}

Our Rivers' Purple Beech are all grafted, and are thrifty stock. The Weeping have had the leaders trained to a stake so that they have a good straight central shoot, unlike most Weeping Beech sold. We call particular attention to the American Beech as being particularly adapted for hedging purposes, where a good hardy ornamental hedge is required. It has been well known for a number of years that the European Beech makes a beautiful hedge, but only lately that the American was equally as fine.

Fraxinus Americana, White

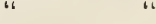

“6

6

16 excelsior, European

lutea, Yellow

"

16

Ornus, Flowering

platycarpa

pubescens, $\mathbf{R e d}$

quadrangulata, Blue

6

sambucifolia, Black

viridis, Creon

" $"$ "

\begin{tabular}{|c|c|c|}
\hline Ash, & $\begin{array}{c}10 \text { to } 15 \text { in. S. } \\
3 \text { to } 4 \mathrm{ft} . . \mathrm{S}\end{array}$ & $\begin{array}{r}35 \\
100\end{array}$ \\
\hline 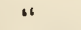 & 5 to $6 \mathrm{ft} . \mathrm{tr}$. & 200 \\
\hline$\because$ & 6 to $8 \mathrm{ft} . \mathrm{tr}$. & 250 \\
\hline$\because$ & 9 to $10 \mathrm{ft} . \mathrm{tr}$. & 350 \\
\hline " & 8 to $10 \mathrm{in.}$. & 35 \\
\hline “ & 6 to $S$ in. $S$. & 35 \\
\hline$" 1$ & 12 to $18 \mathrm{in} . \mathrm{S}$. & 50 \\
\hline 16 & 18 to $21 \mathrm{in} . \mathrm{s}$. & 65 \\
\hline 16 & 2 to $3 \mathrm{ft} . \mathrm{S}$. & 75 \\
\hline .6 & 5 to $6 \mathrm{ft}$. $\mathrm{tr}$. & 200 \\
\hline ઔ & 18 to $24 \mathrm{in} . \mathrm{S}$. & 75 \\
\hline$\because$ & 8 to $12 \mathrm{in} . \mathrm{S}$. & 75 \\
\hline$" 6$ & 18 to 24 in. $S$. & 100 \\
\hline 66 & 3 to $4 \mathrm{ft} . \mathrm{S}$. & 75 \\
\hline$"$ " & 6 to $7 \mathrm{ft} . \mathrm{tr}$ & 300 \\
\hline 16 & 10 to 15 in. $\mathrm{S}$. & 50 \\
\hline " & 2 to $3 \mathrm{ft} . \mathrm{S}$. & 75 \\
\hline ‘. & 4 to $5 \mathrm{ft} . \mathrm{s}$. & 100 \\
\hline " & 3 to $5 \mathrm{ft} . \mathrm{tr}$. & 200 \\
\hline " & 4 to $5 \mathrm{ft} . \mathrm{S}$. & 100 \\
\hline$" 1$ & $6 \mathrm{t} \cap 8 \mathrm{ft} . \mathrm{tr}$. & 300 \\
\hline
\end{tabular}

200

00

500

500

50

800
1000

Ginkgo, sce Salisburia, page 13. 
Cleditschla triacanthos, Honey Locust,

Cymnocladus Canarlensis, Ky. Coffee,

$\begin{array}{lll}\text { " } & \text { ". } & \text { " } \\ " . & \text { ". } & \text { ". }\end{array}$

Hickory, see Carya, page 5.

Hor'nbeam, see Carpinus, page 5.

Horse Chestnut, see Esculus, page 4.

Judas Trce, see Cercis, page 7.

Juglans cinerea, Butternut,

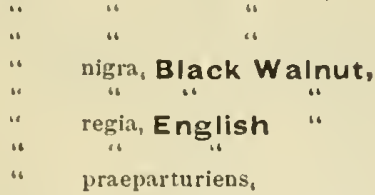

Juneber ry, see Amelanclier, page 4.

Kentucky Codvee, see Gymnocladus, above.

Kolrouteria paniculata,

$$
\begin{array}{ll}
" 1 & \text { " } \\
\text { " }
\end{array}
$$

Laburmum, see Cytisus, page 7.

Larch, sec Larix, below.

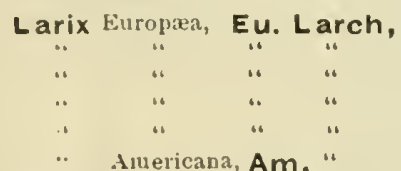

\section{Laurus Benzoil, Spice Wood,}

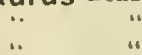

\section{Sassafras,}

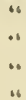

Liuden, see Tilia, page 11.

Liquidambar styracillua, Sweet Cum,

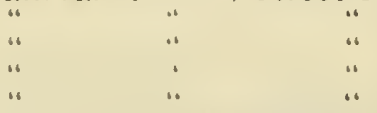

LIriodendron tulipifera، Tulip Poplar,

$\begin{array}{ccc}16 & \text { ". } & \text { ". } \\ \text { ". } & \text { ". } & \text { ". } \\ \text { ". } & \text { ". }\end{array}$

Maclura aurantiaca, Osage Orange,

\begin{tabular}{|c|c|c|}
\hline & P'er 10 & Per 100 \\
\hline 8 to $10 \mathrm{in} . \mathrm{S}$. & $\S 0 \ddot{00}$ & $\$ 150$ \\
\hline 2 to $3 \mathrm{ft} . \mathrm{S}$. & 50 & 300 \\
\hline 6 to 8 in. $S$. & 35 & 200 \\
\hline 12 to $18 \mathrm{in} .8$. & 50 & 300 \\
\hline 3 to $4 \mathrm{ft} . \mathrm{S}$. & 75 & 500 \\
\hline 4 to $5 \mathrm{ft} . \mathrm{S}$. & 100 & S 00 \\
\hline 5 to $6 \mathrm{ft} . \mathrm{tr}$. & $\left.25^{\prime}\right)$ & 2000 \\
\hline
\end{tabular}

Magnolia actminata, Cucumber Tree,

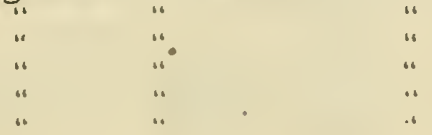

18 to 24 in. $\$$

5 to $6 \mathrm{ft} . \mathrm{S} . \quad 100 \quad 800$

5 to $6 \mathrm{fr}, \mathrm{tr} . \quad 250$

2 to $3 \mathrm{ft}$. S. $\quad 50$

5 to $6 \mathrm{ft}$. S. $\quad \mathrm{l} 00$

2 to $3 \mathrm{ft} . \mathrm{s.} \quad 150$

$f$ to $5 \mathrm{lt}$. S. $\quad 250$

3 to $4 \mathrm{fr} . \mathrm{s}, \quad 250$

8 to 12 in. S. $\quad 35 \quad 200$

10 to 15 in. S. $\quad 50 \quad 300$

2 to $3 \mathrm{ft} . \mathrm{s} . \quad \mathrm{i5}$

3 to $5 \mathrm{fr}$. tr. $\quad 300$

6 to $10 \mathrm{ins}$. S.

4 to 5 it tr. 200

5 to 6 it. tr. $\quad 250$

6 to $8 \mathrm{ft} . \mathrm{tr} . \quad \$ 00$

3 to $\& \mathrm{ft}$.tr. $\quad 300$

6 to 8 ill. $\$$. $\quad 35$

2 to $3 \mathrm{ft} . \$ . \quad 75$

$3 \mathrm{ft} . \mathrm{tr} . \quad 175$

12 to $18 \mathrm{iu} . \mathrm{s} . \quad 65$

18 to $24 \mathrm{in}, \mathrm{s}$. 75

3 to $4 \mathrm{ft}$. tr. $\quad l 50$

+ to $5 \mathrm{ft}, \mathrm{tr}, \quad 200$

5 to $6 \mathrm{Jt}$. tr. $\quad 300$

2000

3000

250

1500

600

410

500

1010

1750

$20 \times 0$

8 to 12 in. S. $35 \quad 200$

2 to $3 \mathrm{ft} . \mathrm{S}$. $\quad 50 \quad 300$

3 to $f$ ft. $\mathrm{s.} \quad 75 \quad 500$

5 to $6 \mathrm{ft}$. tr. $\quad 350 \quad 2500$

6 to $8 \mathrm{tt}$. tr. $\quad+00 \quad 3500$

$1 \mathrm{ft} . \mathrm{tr}$. $\quad 35 \quad 200$

12 to 18 in. tr. $\quad$ to 250

2 to 8 ft. tr. $\quad 60 \quad+00$

3 to $4 \mathrm{ft} . \mathrm{tr}, \quad 100 \quad 600$

5 to $6 \mathrm{ft}$. tr. $150 \quad 1000$

8 to $10 \mathrm{ft}$. $t$. 250

3 to $4 \mathrm{ft}$. tr. Luslyy $\quad 75 \quad 500$

4 to $5 \mathrm{ft}$.tr. $\quad 150$

18 to $2 t$ in. $s$.

2 to $3 \mathrm{ft} . \mathrm{s}$.

3 to $f \mathrm{ft}, \mathrm{s} . \quad 12 \mathrm{~s}$

+ to $5 \mathrm{ft}$. s. $\quad 1.50$

5 to $6 \mathrm{ft}, \mathrm{tr}, \quad 3 \mathrm{t0}$

$\$ 1500$

3000

(5)

1500

600

700

9 on

1250

2000

6 to $8 \mathrm{ft} . \mathrm{tr} . \quad 350$ 
Magnolia Fraseri,

2 to $3 \mathrm{ft} . \mathrm{S} . \quad \$ 400$
3 to $4 \mathrm{ft} . \mathrm{tr} . \quad 500$
8 to $10 \mathrm{ft} . \mathrm{tr} . \quad 750$

A fine sort; flowers large, white, and very fragrant. It makes a tree as large as the acuminata.

Magnolia glauca, Sweet White.

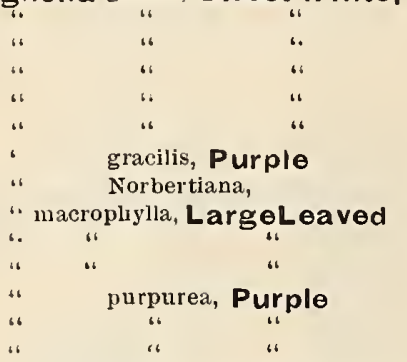

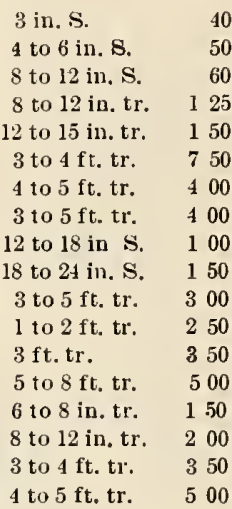

Si2 50

Soulangeanı, Light Pink,

\begin{tabular}{|c|c|c|c|}
\hline "“ & 16 & (very strong ? & 3 to $4 \mathrm{ft} . \mathrm{tr}$. \\
\hline "6 & "6 & i and bushy & 4 to $5 \mathrm{ft}$. $\mathrm{tr}$. \\
\hline
\end{tabular}

Per 100 Per 1000

400

50

Our stock of Soulangeana is exceptionally large aud fine.

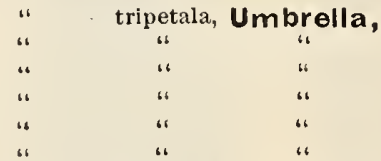

3 to $5 \mathrm{in} . \mathrm{S}$.
6 to $10 \mathrm{in.} \mathrm{s}$.
3 to $4 \mathrm{ft} . \mathrm{S}$
4 to $6 \mathrm{ft} . \mathrm{S}$.
5 to $6 \mathrm{ft} . \mathrm{tr}$.
8 to $10 \mathrm{ft} . \mathrm{tr}$.

Maple, see Acer, page 3.

Melia Azederach, China Treo, Morus alba, Italiau

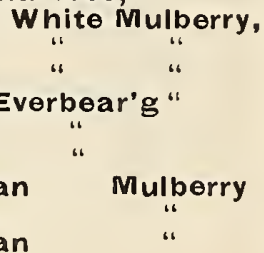
"

\section{Mulberry}

6

:

"1

"6

6

" Japonica, Japan

"Tartarica, Russian

\section{Downing's Everbear'g "}

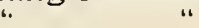

" " " "

Mountain Ash, see Pyrus, page 11.

Mulberry, sce Morus, above.

Negundo fraxinafolium, Ash-leaf Maple, "
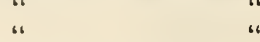

Nettle Tree, see Celtis, page 6.

Nyssa multiflora, Sour Cum,

Oak, see Quercus, page 12.

Ostrya Virginica, Ironwood,

Paliurus aculeatus, Christ Thorn, Paulownia imperialis, Empress Tree,

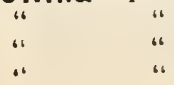

18 to 21 in, tr. 200 12 to 15 in. S. 30 2 to $3 \mathrm{ft}$. $\mathrm{S}$. $\quad 50$ 3 to $4 \mathrm{ft}$. $\mathrm{S} . \quad 60$ 12 to 18 in. tr. 100 2 to $3 \mathrm{ft}, \mathrm{tr} . \quad 150$ 3 to $4 \mathrm{ft}^{\mathrm{t}} \mathrm{tr} . \quad 200$ 2 to $3 \mathrm{ft} . \mathrm{tr} . \quad 75$ 6 to $8 \mathrm{ft}$. $\mathrm{tr} . \quad 200$ 18 to 24 in. S. $\quad 50$ 4 to $5 \mathrm{ft} . \mathrm{S} . \quad 10$,

$1 \mathrm{ft}$. S.

2 to $3 \mathrm{fr}$. S.

4 to $5 \mathrm{ft}$. S.

3 to 4 in. S. $\quad 50$

2 to $3 \mathrm{ft}$. tr. $\quad 400$

18 to 24 in. S. 250

2 to $3 \mathrm{ft}$. tr. 250

3 to $4 \mathrm{ft}$. tr. $\quad 400$

12 to 18 in. S. 200

18 to 24 in. $t r$. 75 .

4 to $5 \mathrm{ft}$, tr. $\quad 150$

5 to $6 \mathrm{ft}$. tr. $\quad 200$

6 to $8 \mathrm{ft}$. tr. $\quad 300$

1200

3000 
Per 10

18 to 24 iu. S. $\$ 200$ 2 to $3 \mathrm{ft}$. S. $\quad 250$

12 to 18 in. S. $\quad 100$ 2 to $3 \mathrm{ft} . \mathrm{s} . \quad 16 ?$ 5 to $6 \mathrm{ft}$. tr. $\quad 350$

Plane, see Plintanus, below.

Planera cuspidata, " liaki

Platanus occiclentalis, Am. Plane,

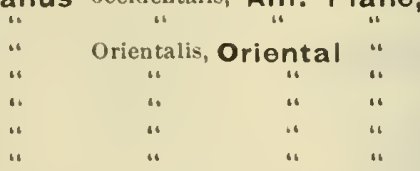

Poplar, see I'opulus, below.

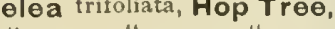

Pyrus aucuparia, Eu. Mt. Ash,

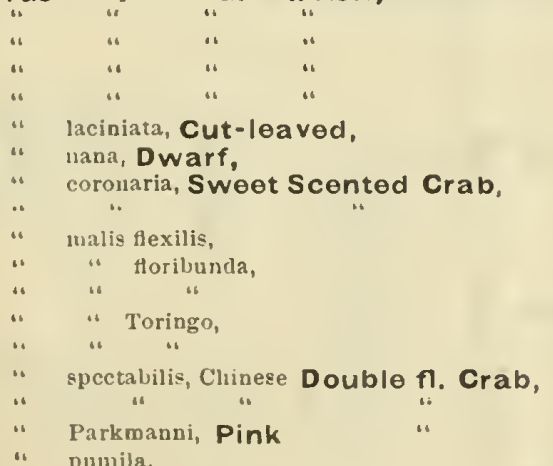

Sassafras, see Laurus, page 9.

Sour Gum, see Ny'ssa, page 10.

Spice Wood, see Laurus, page 9.

Sweet Gum, see liquidambar, page 9.

$10 \mathrm{ft}$. $\mathrm{tr}$.

\section{0}

18 to 24 in.tr. $\quad 50$

18 to 24 in. $t r . \quad 150$

3 to $4 \mathrm{ft}, \mathrm{tr}$. $\quad 200$

4 to $5 \mathrm{ft}$. tr. 250

$2 \mathrm{ft}$. tr.

5 to $6 \mathrm{ft}$. tr. $\quad 100$

10 to 12 ft.tr. $\quad 200$

2 ft. tr. $\quad 35$

5 to $6 \mathrm{fr}, \mathrm{tr} . \quad 100$

10 to $12 \mathrm{ft}, \mathrm{tr}, \quad 300$

$2 \mathrm{ft}$. tr. $\quad 35$

4 to $5 \mathrm{ft}$. tr. $\quad 50$

10 to $12 \mathrm{ft}$. $\mathrm{tr} . \quad 200$

$2 \mathrm{ft}$. tr. $\quad 100$

6 to $8 \mathrm{ft}$. tr. 250

18 to 24 in. $\quad 200$

5 in. S. $\quad 50$

10 to $15 \mathrm{in.} \mathrm{S}$, 7.5

18 to 24 in. tr. 150

12 to $15 \mathrm{in.} \mathrm{tr} . \quad 60$

2 to $3 \mathrm{ft}$ tr. 100

3 to $4 \mathrm{ft} . \mathrm{tr} . \quad 125$

4 to $5 \mathrm{ft}$. tr. $\quad 150$

j to $6 \mathrm{ft}$. tr. $\quad 175$

5 to $6 \mathrm{ft} . \mathrm{tr}, \quad 250$

3 to $4 \mathrm{ft}$. $t$. $\quad 250$

18 to $24 \mathrm{int} \mathrm{S}$. J 50

3 to $1 \mathrm{ft} . \mathrm{tr} . \quad 250$

4 to $5 \mathrm{ft} . \mathrm{tr} . \quad 250$

$3 \mathrm{ft}$. tr. 200

4 to $5 \mathrm{ft}$. tr. $\quad 250$

$3 \mathrm{ft}$. tr. $\quad 200$

5 to $6 \mathrm{ft}$. tr. $\quad 300$

3 it. tr. 200

4 to $5 \mathrm{ft}$. $\mathrm{tr} . \quad 250$

3 to $f \mathrm{ft} . \mathrm{tr} . \quad 350$

3 to $5 \mathrm{ft}$. tr. $\quad 350$
Per 100 Per 1000

$\$ 600$

200

500

1000

1300

1800

$\$ 5000$ 6000 15000
200

200

800

2500

200

300

1500

12500 


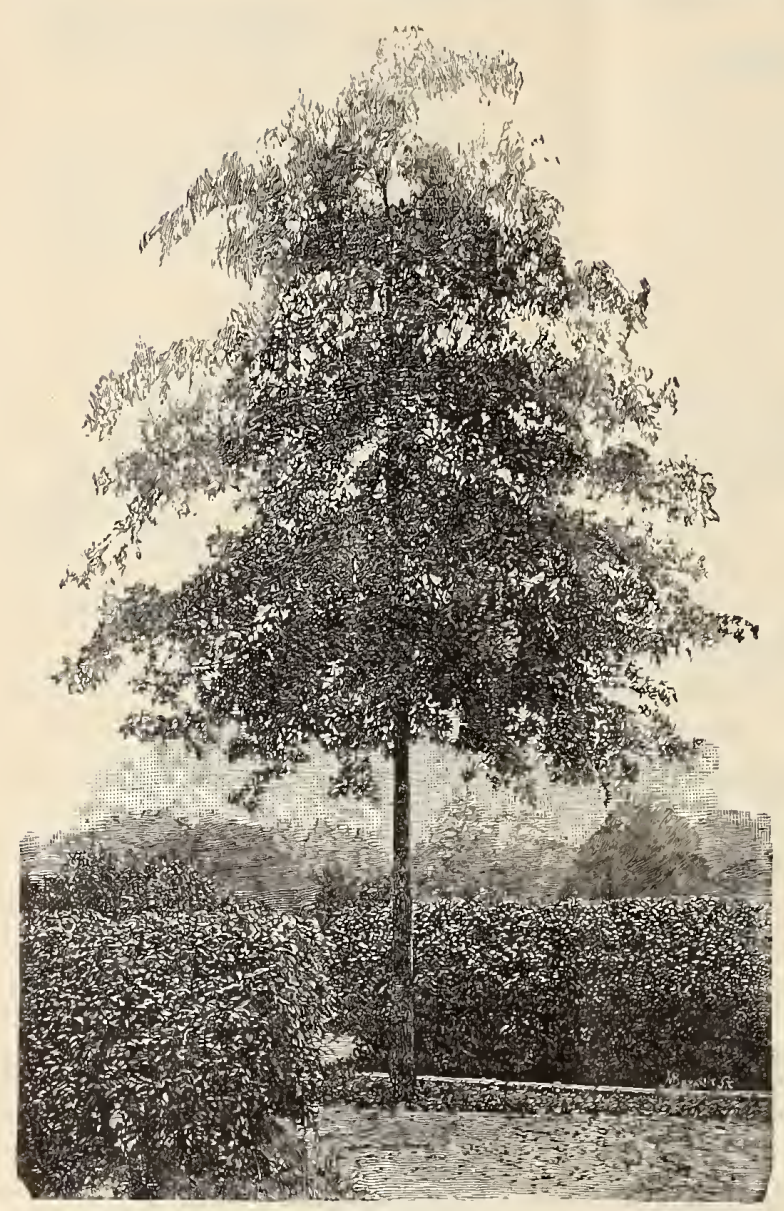

OAKS.

Oaks are our specialty, and we have the $\mathrm{l}$ argest quantity of them of any nursery in the country.

At one time they had the reputation of being of slow growth. While this may be true of them in Europe it is not so here. In our nursery they grow just as fast as any other ordinary tree. Our sales of them increase every year. The White, Scarlet, MossyCup, Pin, Red and Black, are particularly fine sorts.

Quercus palustris-(Piu Cak.) 10 jears' growth; 20 feet liinll.

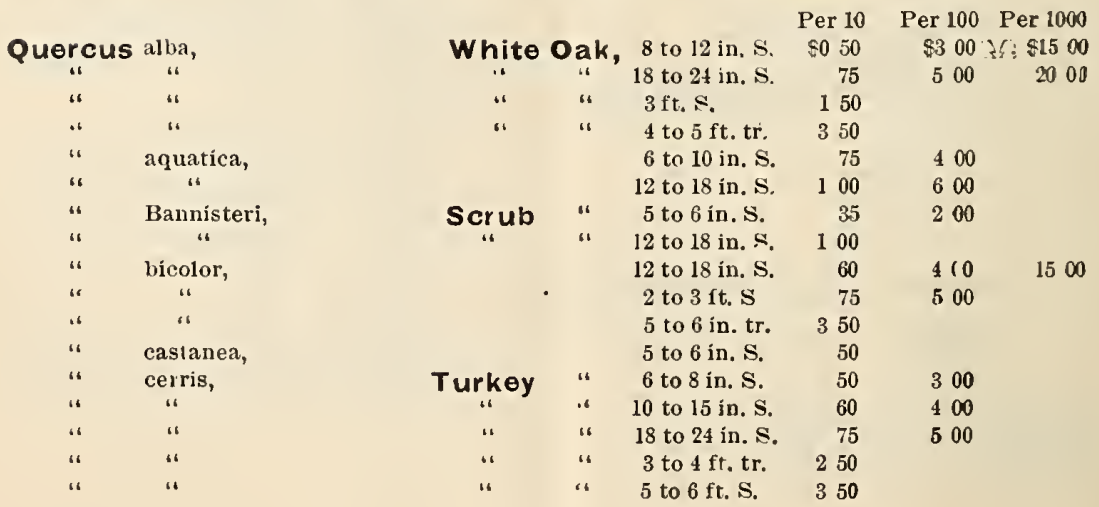


Quercus coccinea,

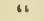

a

$\rightarrow$

6

imbricaria,

"

Igrata,

inacrocarpa,

s6

6

Michauxii

nigra,

obtusiloba,

olivæformis

แ

palustris,

it

a

a

at

palustri-inbricaria,

Phellos,

prinoides,

Dwarf Chestlow

Prinus,

Rock Chestnut

16

rohur, English

แ"

16

" fastigiata, Upright

rubra, Red

" "

164

46

tunctorla, Black

$$
\text { " " }
$$

Robinia psued-acacia, Yellow Locust, Salisburia adiantifolia, Cingko,

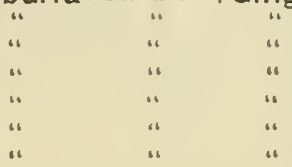

\section{Salix alba,}

annularis, Curled

Whlte Willow,
Scarlet Oak, 5 to 6 in. S. $\$ 035$ 8 to 12 in. S. 50 3 to $4 \mathrm{tc}$. S. $\quad 175$ 3 to 5 ft. tr. $\quad 350$ 5 to $6 \mathrm{ft}$. tr. $\quad E 00$ 6 to $8 \mathrm{ft}$. tr. $\quad 750$ 6 to 8 in. s. $\quad 50$ 10 to 15 in. S. 60 4 to $5 \mathrm{ft} \mathrm{S.} 200$ $1 \mathrm{ft} . \mathrm{s}$. 75 8 to 10 in. $\mathrm{S}$. $\quad 50$ 18 to 24 in. S. 75 3 to $4 \mathrm{ft}$. S. $\quad 100$ 6 to $8 \mathrm{ft} . \mathrm{tr} . \quad 400$ 8 to 12 in. $s .100$ 6 to 10 in. S. 50 12 tu 18 in. S. 60 6 to $10 \mathrm{in.} \mathrm{S.} 50$ 3 to $4 \mathrm{rt}, \mathrm{s} . \quad 125$ 6 to s ft. tr. 500

Pin " 6 in. S. 35
$\begin{array}{ll}6 \text { ill. S. } & 35 \\ 12 \text { to } 15 \mathrm{in.S.} & 60\end{array}$ 2 to 3 ft. S. $\quad 100$ 3 to $4 \mathrm{ft}$. S. 1 to $5 \mathrm{ft}, \mathrm{tr}$ 5 to $6 \mathrm{ft}$. tr. 600 6 to 8 ft. tr. $\quad 750$ 6 to 12 in. $s . \quad 100$ 10 to $15 \mathrm{in.S.} \quad 75$ 6 in. S. 40 10 to 15 in. S. $\quad 60$ 6 to 8 in. $\mathrm{S}, \quad 50$ 12 to $18 \mathrm{in.S.} \quad 60$ 5 to $6 \mathrm{ft}$. tr. $\quad 500$ 6 to 8 ill. S. 35 18 to $24 \mathrm{in.S}$. 50 4 to $5 \mathrm{ft}$. S. 200 6 to $8 \mathrm{ft}$. $\mathrm{tr}$. $\quad 500$ 5 to $6 \mathrm{ft}$. $\mathrm{tr} . \quad 850$ 6 to 8 in. $S$. 35 12 to 18 in. 8 . 60 3 to $4 \mathrm{ft}$. S. $\quad 150$ 5 to $6 \mathrm{ft}, \mathrm{tr} . \quad 600$ 6 to $8 \mathrm{ft}$. tr. $\quad 750$ 5 to 6 in. $S$. 2 to $3 \mathrm{ft}$. $\mathrm{S}$. 5 to $6 \mathrm{ft}$. tr. 5 to $6 \mathrm{ft}$. $\mathrm{s}$.

5 to 6 in. S. 6 to 8 in. S. 8 to 12 in. S. 12 to 18 in. 5 . 18 to $24 \mathrm{in} .5$. 3 to $4 \mathrm{ft}$. $\mathrm{tr}$. 1 to $5 \mathrm{ft}$. $t r$. 2 to $3 \mathrm{ft}$. tr. 18 to $24 \mathrm{ill}, \mathrm{tr}$.

\section{$2 \mathrm{ft}$. tr.}

5 to $6 \mathrm{ft}$. $\mathrm{tr}$.

2 to $31 \mathrm{t}, \mathrm{tr}$.

18 to $24 \mathrm{in}, \mathrm{tr}$.

2 to $3 \mathrm{ft}$. $\mathrm{tr}$.

$5 \mathrm{ft} .1 \mathrm{r}$.
Per 100 Per 1000

$\$ 200 \quad \$ 1200$

$300 \quad 1500$

1500

3000

4000

300

400

300

2000

500

300

400

300

2500

2000

$200 \quad 1200$

400

700

4000

5.500

$6 \overline{5} 00$

500

300

400

203

400

$200 \quad 1200$

$400 \quad 1600$

1000

5000

200

1200

Forbsana, 


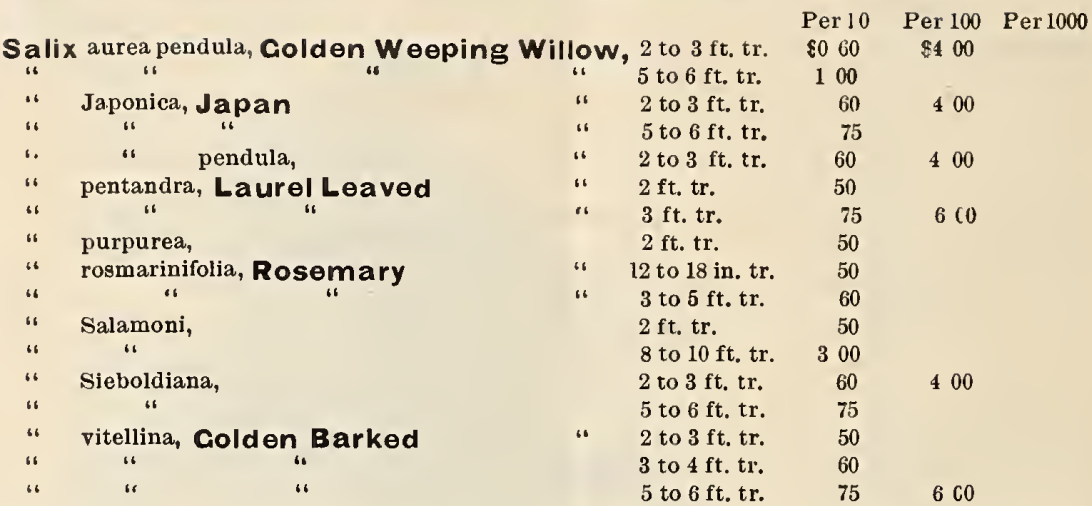

Besides the above willows we have the following sorts, which can be furnished in about the same sizes and at same rates as the others : candida, cordata, myricoides, Russeliana, Villarsiana, pyrifolia, discolor, acutifolia, hippophæfolia, lucida, viminalis, cinerea Medenii, dasyclados, sericea, regalis.

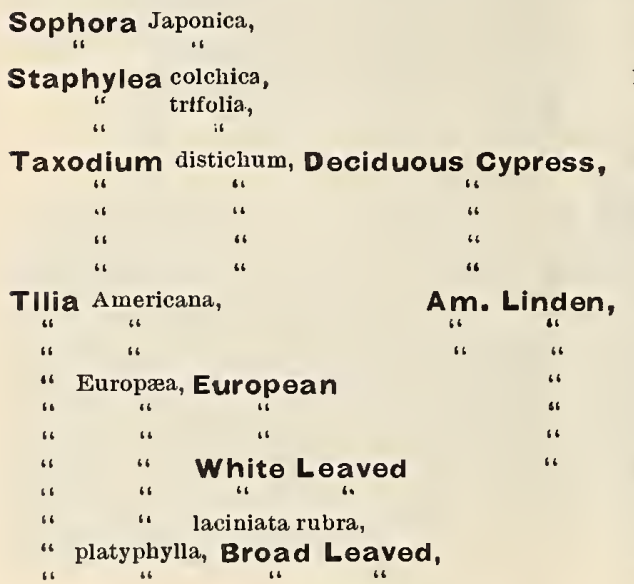

8 to 12 in $\mathrm{S}$. $\quad 75$

18 to 24 in. S. 150

12 to 18 in. tr. 150

4 to 5 in. S. 50

8 to 12 in. S. $\quad 75$

8 to 12 in. S. $\quad 50$

18 to 24 in. S. 75

2 to $3 \mathrm{ft}$. S. $\quad 100$

3 to 4 ft. S. 125

5 to $6 \mathrm{ft}$. tr. $\quad 250$

5 to 6 in. S. $\quad 50$

6 to 10 in. S. $\quad 75$

5 to 6 ft. tr. $\quad 300$

2 to $3 \mathrm{ft}$. S. $\quad 100$

3 to $5 \mathrm{ft}$ tr. $\quad 200$

6 to $8 \mathrm{ft}$. tr. $\quad 300$

2 to $3 \mathrm{ft}$. tr. $\quad 200$

3 to $4 \mathrm{ft}$. tr. $\quad 300$

2 to $3 \mathrm{ft}$. tr. $\quad 300$

5 to 6 in. S. $\quad 50$

6 to 10 in. $\mathrm{S}$. $\quad 60$

Tulip Poplar, see Liriodendron, page 9.

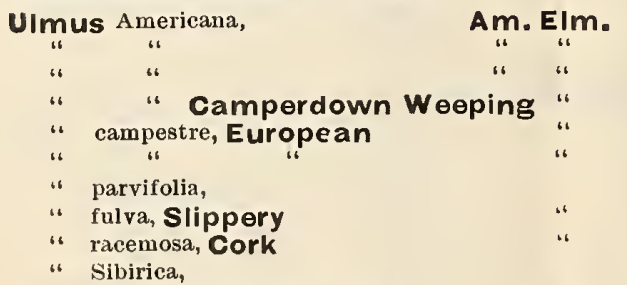

2 to $2 \frac{1}{2} \mathrm{ft}$. S. $\quad 50 \quad 400 \quad 2000$ 6 to $8 \mathrm{ft}$. tr. $250 \quad 2000$ 8 to $10 \mathrm{ft}$. tr. $\quad 350$ 5 to $6 \mathrm{ft}$. tr. $\quad 500$ 12 to $18 \mathrm{in}, \mathrm{tr} . \quad 40$ 4 to $5 \mathrm{ft}$. tr. $\quad 150$ 8 to 12 in. tr. 200 6 to $8 \mathrm{ft}$. $\mathrm{tr}, \quad 300$ 3 to $5 \mathrm{ft}$. tr. $\quad 350$ 8 to 12 in. 200

Weeping Beech, see Fagus, page 6.

Weeping Birch, see Betula, page 5.

Weeping Dogwood, see Cornus, page 6.

Weeping Willow, see Salix, page 13.

Walnut, see Juglans, page 9 


\section{Deciduous Shrubs.} rows.

46. "Tr." signifies the stock is transplanted; "S." is in seed beds, and "C." in cutting Amorpha canescens, Indigo Shrub,
fruticosa,

Per 10 Per 100 Per 1000

Alther, see Hibiscus, page 17.

\begin{tabular}{|c|c|c|}
\hline & Per 10 & Per 100 \\
\hline 12 to $18 \mathrm{in} . \mathrm{S}$. & $\$ 060$ & $\$ 100$ \\
\hline 8 to 12 in. $\mathrm{S}$. & 35 & 200 \\
\hline 2 to $3 \mathrm{ft} s$. & 50 & 300 \\
\hline 4 to $5 \mathrm{ft} . \mathrm{s}$. & 100 & \\
\hline
\end{tabular}

Amygdalus nana, Double White

Andromeda Mariana, ، Pink

Flowering Almond, $2 \mathrm{ft}$, tr.

\section{Andromeda racemosa, "ligustrina, recurva,}

Azalea arborescens, white,

" calendulacea, flame,
"
" $\quad$ viscosiora, light pink,
"white,

viscosa, white,

Baccharis halimifolia,

Berboris Thunbergii, Japan Berberry.

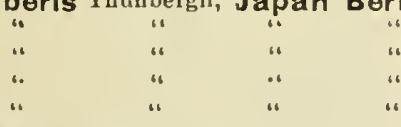

$2 \mathrm{ft}, \mathrm{tr}, \quad 150$

12 to 15 in. tr. 200

18 to 24 in. tr. 200

12 to 15 in. tr. 200

12 to 18 in tr $3 \mathrm{CO}$

18 to 24 in. $t r . \quad 2$ : 0

12 to $15 \mathrm{in.}$ tr. 250

18 to 24 in. tr. 650

10 to $12 \mathrm{in.}$ tr. $\quad 200$

6 to 8 in. tr. $\quad 150$

$1 \mathrm{ft}$. tr. $\quad 200$

$3 \mathrm{ft}$. tr. $\quad 250$

8 to 10 in. S. 50

10 to $15 \mathrm{in.} \mathrm{S}$. 65

12 to $18 \mathrm{in.} \mathrm{s} . \quad 100$

18 to 21 in. $t r . \quad 150$

2 to $21 / 2 \mathrm{ft}, \mathrm{tr} . \quad 250$

4he finest plant for dwart hedges. Leaves turn deep scarlet in fall.

$$
\begin{array}{ccc}
\text { " } & \text { vulgaris, Common " } \\
\text { " } & \text { " } \\
\text { " } & \text { " Purple Leaved, }
\end{array}
$$

Buckthorn, see Rhamnus, page 20.

Callicarpa purpurea,

$$
\text { “Japonica, }
$$

Calycanthus fioridus, Sweet Shrub,

\section{Caragana arborescens, Siberian Pea,}

Cassia Marilandica,

Cephalanthus occidentalis, Dwf. Button Ball

Chionanthus Virginica, White FrInge,

\section{Citrus trifoliata, Hardy Orange,}

Clerodendron Bungei,

Clethra alnifolia, Sweet Pepper Bush,

Colutea arlorescens
6 in. S. $\quad 30$

12 to $18 \mathrm{in} . \mathrm{S} . \quad 50$

6 in. $\mathrm{s} \quad 35$

18 to 24 in. $8 . \quad 75$

5 to 6 in. S. $\quad 30 \quad 200$

12 to 18 in. C. $75 \quad 500$

12 to 18 in. C. 75

18 to 24 in. C. $\quad 100$

6 in. 5 . $\quad 30$

2 to $3 \mathrm{ft} .4500$

5 to) 6 in. S. $\quad 25 \quad 150$

6 to $10 \mathrm{in} . \mathrm{S}, \quad 35 \quad 250$

18 to 21 in. S. 100

$2 \mathrm{ft} . \mathrm{s} . \quad 100$

6 in. 5 .
2000

3000 


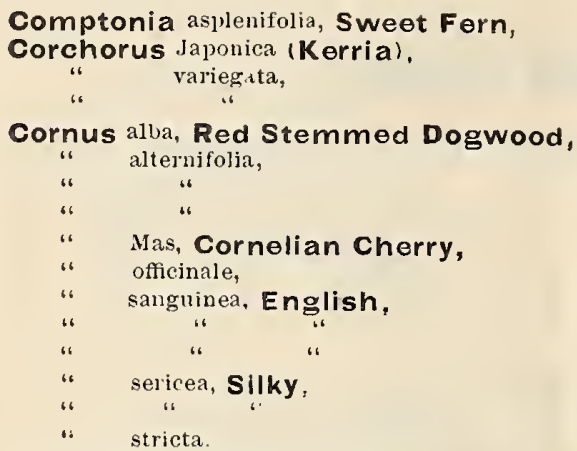

12 to 15 in $t$.

2 to $21 / 2 \mathrm{ft}, \mathrm{tr}, 100$

10 to 12 in.tr 75

2 to $2 \frac{1}{2}$ It. t.r. $\quad 125$

2 to $3 \mathrm{ft}$. C. $\quad 100$

6 to $8 \mathrm{in.} \mathrm{S.} \quad 50$

12 to $18 \mathrm{in}$. S. $\quad 1-00$

2 to $3 \mathrm{ft} . \mathrm{S}$. $\quad 150$

18 to 24 in. S. 100

3 to $4 \mathrm{ft}$. S. $\quad 200$

12 to $18 \mathrm{in.} \mathrm{S.} 100$

2 to $3 \mathrm{ft}$. S. $\quad 125$

4 to $5 \mathrm{ft} . \mathrm{tr}$. 200

18 to $24 \mathrm{nn}$. C. 150

$21 / 2$ to $3 \mathrm{ft}, \mathrm{tr} .200$

12 to 18 in. C. 75

For Cornus flor $₫ d a$, mbro and pendula, see Trees, page 6 .

\section{Corylus avellana, Hazel,}

unacrocarpa, Filbert,

purpurea, Purple Filbert,

Americana,

"

Merveille re Bollevieller, Lar

Bergeri,

cieante rle Halle,

Cotoneaster simmondsi

" Wliceleri,

Cratagus cocrinea,

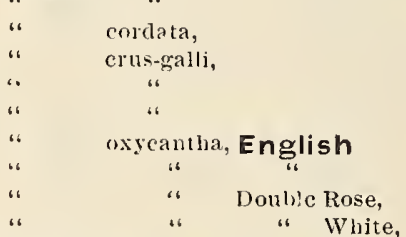

Cydunia, see Pyrus Japonica, pige 19.

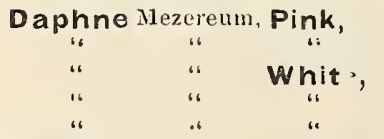

Desmodium Japnnin"um, White,

" penduliflorum, (Lespedeza Sieboldi,) Pink

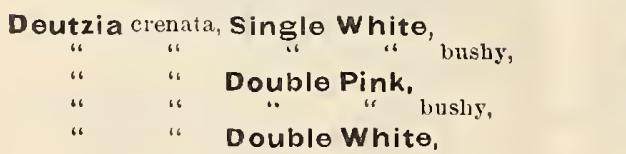

Fortuni, White,

" bushy,

$$
\begin{array}{ccc}
\text { Fortun, White, } \\
\text { ". } \\
\text { ". } & \text { " } & \\
& &
\end{array}
$$

gracilis, Dwarf White, clumps,

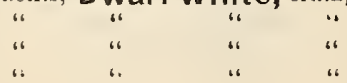

$2 \mathrm{ft} . \mathrm{tr} . \quad 250$
8 to 12 in. S. $\quad 50$.

4 to $5 \mathrm{ft} . \mathrm{tr} . \quad 300$

6 to 8 in. tr. $\quad 100$

12 to 18 in. tr. 175

$1 \mathrm{ft} . \mathrm{S}$. $\quad 100$

12 to 15 in. tr 200

$2 \mathrm{ft} . \mathrm{tr} . \quad 500$

18 to $24 \mathrm{in}, \mathrm{tr} . \quad 350$

4 to $5 \mathrm{ft}, \mathrm{tr} . \quad 150$

$1 \mathrm{ft} . \mathrm{tr} . \quad 100$

$3 \mathrm{ft} . \mathrm{tr} . \quad 150$

8 to 10 in. S. $\quad 75$

1) to 24 in. S. 125

18 to 24 in. $s \quad 100$

8 to 12 in. S. $\quad 75$

12 to 18 in. S. 100

$2 \mathrm{ft} . \mathrm{S} . \quad 150$

18 to 24 in. S. $\quad 50$

12 to $18 \mathrm{in}, \mathrm{tr} . \quad 100$

3 to $4 \mathrm{ft} \mathrm{tr} . \quad 360$

3 to $4 \mathrm{ft}$. $\mathrm{tr}$. $\quad 35$ ?

3 in. S. $\quad 75$

$2 \mathrm{ft.tr}$. $\quad 250$

500

800

500

800

1200

250

600
1000

3000

$\$ 3000$

(2)

3 in. $\mathrm{s.} \quad 50$

18 to 24 in, tr. 175

1 year tr. $\quad 200$

2 vear tr. 250

400

1500

2000

400

500

400

500

400

500

$2 \mathrm{ft}$. C.

$3 \mathrm{ft} . \mathrm{C}$.

$3 \mathrm{ft}$. tr.

6 in. $\mathrm{tr}$.

$1 \mathrm{ft} . \mathrm{tr}$.

400

800

12 to $18 \mathrm{in.}$ tr. $\quad 100$

18 to 24 in. tr. 125 
Deutzia Pride of Rochester, Double Pink and

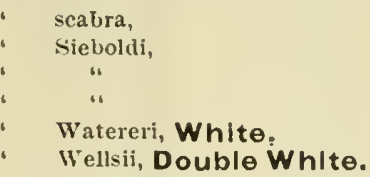

Dogwood, see Cornus, pages 6 and 16 .

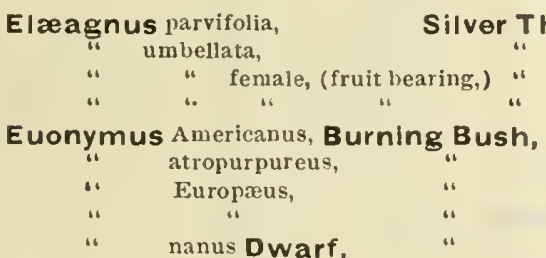

Exochorda grandiflora,

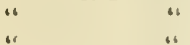

Flowering Almond, see Amygdalus, page 15.

Forsythia viridissima, Colden Bell,

\begin{tabular}{|c|c|}
\hline । & 11 \\
\hline "1 & " \\
\hline$" 1$ & "1 \\
\hline "“ & " \\
\hline "“ & suspensa, \\
\hline "* & \\
\hline “" & $\begin{array}{l}\text { Fortuni, } \\
\text { "variegata }\end{array}$ \\
\hline
\end{tabular}
Caylussacia resinusa, Huckleberry,

Conista scoparia, Scotch Broom,

Golden Bell, see Forsythia, above.

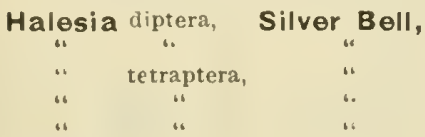

Hamamelis Virginica,

Hardy Orange, see Citrus, page 15.

Hawthorn, see Cratrgus, page 16.

Hazel, see Corylus, page 16.

\begin{tabular}{|c|c|c|c|c|}
\hline Hibiscus & Double Bluish Lilac, & $1 \mathrm{ft} . \mathrm{tr}$. & 40 & \\
\hline " & 40 & 12 to 13 iu. tr. & 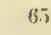 & 500 \\
\hline “ & $"$ & $21 / 2$ to $3 \mathrm{ft} . \mathrm{tr}$. & 125 & 1000 \\
\hline " & " $\quad$ " & ft. tr. & 15 & 1200 \\
\hline$\because$ & Double Rosy Lilac, & $\begin{array}{l}1 \mathrm{ft} . \mathrm{tr} \\
1 \text { s to } 24 \mathrm{iu} . \mathrm{tr} \text {. }\end{array}$ & $\begin{array}{l}40 \\
75\end{array}$ & \\
\hline
\end{tabular}

8700

300

3 to $4 \mathrm{ft}$. S. $\quad 150$

18 to 24 in. C. 150

5 to $6 \mathrm{ft}$. C. $\quad 250$

12 to $18 \mathrm{lu} . \mathrm{tr}^{\circ} . \quad 100$

5 to 6 in.s. $\quad 50$

5 to 6 in. $s$. $\quad 50$

12 to $18 \mathrm{in} . \mathrm{S} . \quad 75$

12 to 15 in. tr. 200

5 to 6 in. S. $\quad 50$

18 to $2 \&$ in. S. $\quad 85$

2 to $3 \mathrm{ft}$. tr. 200

$1 \mathrm{ft} . \mathrm{C} . \quad 40 \quad 300$

12 to 18 iu. C. $65 \quad 400$

$2 \mathrm{fc}, \mathrm{tr} . \quad 75 \quad 600$

$2 \frac{1}{2}$ to $3 \mathrm{ft}, \mathrm{tr} . \quad 100 \quad 800$

3 to $4 \mathrm{ft}$. tr. $\quad 150$

$1 \mathrm{f} . \mathrm{C}$. 50

$2 \mathrm{ft} . \mathrm{tr}$. $\quad 125$

2 to $2 \frac{1}{2} \mathrm{ft}, \mathrm{tr} . \quad 100$

$1 \mathrm{ft}, \mathrm{C}$. $\quad 75$

$1 \mathrm{ft} . \mathrm{tr} . \quad 100$

12 to 15 in. tr. 200

2 to $3 \mathrm{ft}$. S. $\quad 100$

4 to $5 \mathrm{ft} . \mathrm{S}$.

1200

6 to $8 \mathrm{in.} \mathrm{S.} \quad 75$

12 to 18 in. S. $1 \mathrm{CO}$

5 to 6 in. $\mathrm{S}$. $\quad 50$

18 to 24 in. S. $\quad 100$

2 to $3 \mathrm{ft}, \mathrm{s}, \quad 125$

3 to $5 \mathrm{in.} . \mathrm{S}$. 65

6 to 8 in. 6.

2 to $2 \frac{1}{2} \mathrm{ft}$. tr. 250 


\section{Hibiscus Double Red, \\ Double Cream, dark centre, Double Dark Red,

Hippophæa rhamnoides,
Per 10 Per 100 Per 1000

1 ft. tr $\$ 040 \quad \$ 300$

18 to 24 in.tr. $\quad 75 \quad 500$

18 to 24 in. tr. $\quad 85 \quad 600$

$1 \mathrm{ft}$. tr. $\quad 50 \quad 400$

12 to 18 in. tr. $\quad 75 \quad 600$

$1 \mathrm{ft}$. tr. 50

18 to 24 in. $t r$. $\quad 75$

$1 \mathrm{ft}, \mathrm{tr}$. 50

$2 \mathrm{ft} . \mathrm{tr}$. $\quad 75$

$1 \mathrm{ft} . \mathrm{tr}$. $\quad 50$

18 to 24 in, tr. 75

3 to $33 / 2$ ft. tr. $\quad 150$

$1 \mathrm{ft}$. tr. $\quad 50$

12 to 18 in. tr. 100

3 to 4 ft. tr. $\quad 250$

Huckleberry, see Vaccininm, page 23, and Gaylussacia, page 17.

Hydrangea arborescens,

$$
\begin{array}{cc}
\text { "6 } & \text { paniculata, } \\
\text { "6 } & \text { "“ } \\
\text { " } & \text { ". } \\
\text { ". } & \text { ". } \\
\text { " } & \text { radiata, }
\end{array}
$$$$
\text { " " grandiflora, }
$$$$
\text { " " " }
$$

Standards

$$
\text { quercifolia, Oa }
$$

calycinum,

densiflorum,

Moserianum,

patulum,

prolificum,
2 to $3 \mathrm{ft}$ tr. $\quad 250$

12 to 18 in. tr. 150

12 to 18 in. tr. $\quad 75$

2 to $2 \frac{1}{2} \mathrm{ft}$. tr. $\quad 90$

$2 \frac{1}{2}$ to $3 \mathrm{ft}$. tr. $\quad 100$

3 to $4 \mathrm{ft}$. tr. $\quad 150$

3 to $4 \mathrm{ft}$. tr. $\quad 200$

18 to 24 in. tr. 200

$1 \mathrm{ft}$. tr. $\quad 2 \mathrm{CO}$

$1 \mathrm{ft}, \mathrm{tr}$. $\quad 125$

$1 \mathrm{ft} . \mathrm{tr}$. $\quad 125$

$2 \mathrm{ft}$.tr. $\quad 150$

12 to 15 in. tr. 200

$1 \mathrm{ft}$. $\quad 125$

18 to 24 in. tr. $\quad 150$
$500 \$ \$ 1000$

$6 \mathrm{r0} \quad 5000$

$700 \quad 6000$

$1200 \quad 10000$

1000

1800

The Moserianum has large yellow flowers, very fine for massing or planting along edges of shrubbery beds. Thrives in dry places.

Ilex monticola,

Itea Virginica,

Japan Snowball, see Viburnum, page 23.

Japan Quince, see Pyrus, page 19.

Kerria, see Corchorus, page 16.

Lagerstraemia Indica, Crape Myrtle, Pink, 2 to 3 ft. tr. 350

Lespedeza bicolor,

Leycesteria formosa,

Ligustrum buxifolium,

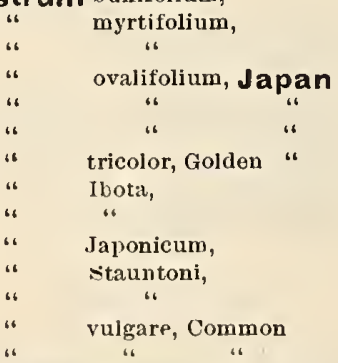

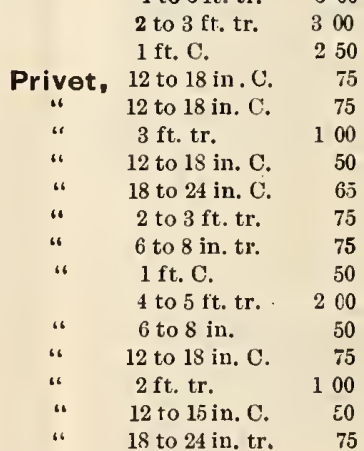

2000 3000 5000

Lilac, see Syringa, page 22 .

Lonicera fragrantissima, Bush Honeysuckle, 18 to 24 in. C. 85 
Lonicera Korolkowii, Bush Honeysuckle, Ledebouri,

Orientalis,

Philomelæ,

Sibirica,

Tartarica,

.

"

grandiflora, PInk

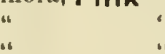

Xylosteum, Fly Moneysuckle,

Ruprechilana,
I'er 10

18 to 21 in. C. $\$ 150$

$1 \mathrm{ft} . \mathrm{C}$. 85

Ift. C. $\quad 75$

$3 \mathrm{ft} . \mathrm{C} . \quad 100$

$1 \mathrm{ft}$. C. $\quad 75$

is to $24 \mathrm{in}$. tr. $\quad 100$

12 to 18 in C. $\quad 75$

$3 \mathrm{ft}$. C. $\quad 85$

$1 \mathrm{ft}$. 0 . 75

18 to 24 in. tr. 100

$3 \mathrm{ft}$. C. $\quad 125$

12 to 18 in. C, 65

3 to $4 \mathrm{ft}$. C. $\quad 100$

12 to 18 in. $t r . \quad 100$

12 to 18 in. C. 65

3 to $4 \mathrm{ft} . \mathrm{C} . \quad 100$

18 to 24 in. C. 100

Per 100 Per 1000

$\$ 500$

800

800

510

$21 / 2$ to $3 \mathrm{ft} . \mathrm{tr} . \quad 150$ $1 \mathrm{ft}$. C. $\quad 100$

3 ft. C. $\quad 150$

1250

1250

Myrica cerifera, Wax Myrtle

Noviusia Alabamensis,

Pepper Bush, see Clethra, page 15.

Phlladolphus coronarius, aureus, Gordonianus

Mock Orange, 2 to $3 \mathrm{ft} . \mathrm{tr} . \quad 150$ 12 to 15 in tr. 150 12 to 18 in. C. 100 3 to $4 \mathrm{ft}$. tr. $\quad 150$ 12 to 18 in. C. 100 18 to 24 in tr. 125 12 to 18 in. C. 100 grandiflorus

\section{Zeyheri}

PhotInla villosa, semi-plena

3 to $4 \mathrm{ft}$. tr. bushy 200 8 to $10 \mathrm{ft}$. $\mathrm{S}$. $\quad 75$ 2 to $3 \mathrm{ft} . \mathrm{S} . \quad 150$ 3 to $4 \mathrm{ft}$. S. $\quad 250$ 6 in. S. 12 to 18 in. S. 100 5 to 8 in. S. 75 10 to $15 \mathrm{in.} \mathrm{S.} 100$ 2 to $3 \mathrm{ft} .1 \mathrm{r} .200$

Prinos verticillatus,

"1

Privet, see Ligustrum, page 18.

Prunus Americana,

maritiıa

Pissardi, Purple-leaved PIum,

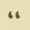

spinosa flore plena, triloba, dbl. ก. Plum,

Pterostyrax hispudum,

Purple Plum, see Prunus, above.

Pyrus arbutifolia,

Japonica, (Cydonia Japoni a)

PInk.

White,

Maulei, Orange.

3 to 4 ft. S. 2 .

6 to $8 \mathrm{in}$. tr. $\quad 75$

1 to 2 ft. tr. 125

18 to 24 in. S. 150
18 to 24 in. S. $\quad 100$

$t$ to $5 \mathrm{ft}$. S. $\quad 200$

3 to $4 \mathrm{ft}$. S. $\quad 250$

18 to $21 \mathrm{in}, \mathrm{tr}$. 65

2 to $3 \mathrm{ft}$. tr. $\quad 85$

3 to $4 \mathrm{ft}$. tr. $\quad 100$

$5 \mathrm{ft}$. $\quad 150$

18 to 24 in. tr. 200

2 to $21 / 2 \mathrm{ft}$. tr. 100

12 to $15 \mathrm{ins}$ tr, 150

18 to 24 in S. $\quad 175$

500

700

800

800

1200

1500

2000

2 ft. tr.

150

6 to $8 \mathrm{in}$. tr.

50

$120 \mathrm{~J}$

12 to 18 in. tr.

$+00$

600

$\$ 2500$

$2 \mathrm{ft}$. $\mathrm{tr}$.

100

800 
Rhamnus Carolinianus, Carolina Buckthorn,
"
" catharticus, Common "
" crenatus,

40- The catharticus is the sort used for hedging.

Rhodotypus kerrioides,

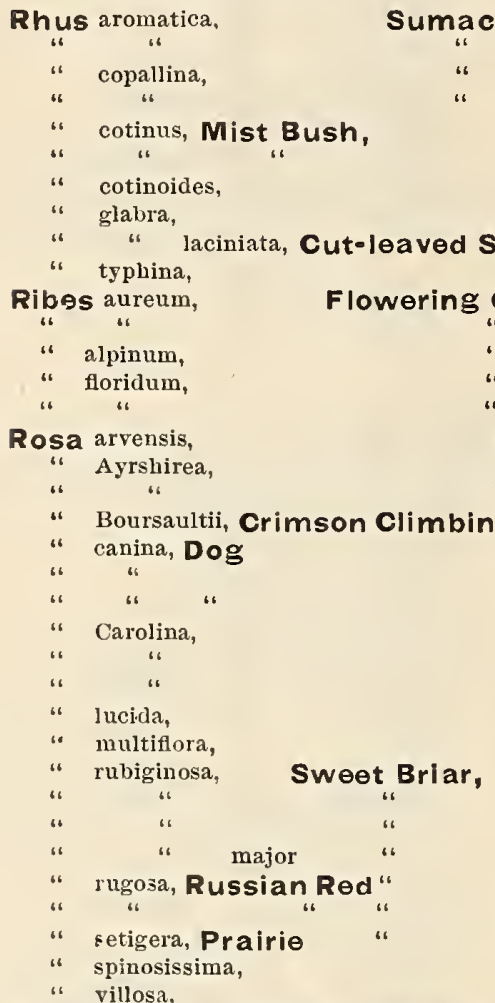

Rubus fruticosus, Flowering Bramble, odoratus,

Sambucus aurea, Colden Elder,

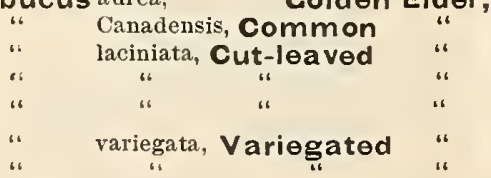

Scotch Broom, see Genista, page 17.

Silver Bell, see Halesia, page 17 .

Silver Thэrn, see Elæagnus, page 17.

Snowball, see Vihurnum, page 23.

Spiræa ariæfolia, White,

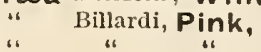

Per 10

8 to 12 in. S. $\$ 075$ 3 to $4 \mathrm{ft}$. $\mathrm{s}$. $\quad 150$ 12 to 18 in. S. $\quad 50$

18 to 24 in. $8 . \quad 75$ 18 to 24 in. S. $\quad 150$

$1 \mathrm{ft} . \mathrm{C}$. $\quad 85$

Rose, 18 to 24 in. S. 150
8 to 12 in. S. $\quad 75$ 12 to 13 in. S. $\quad 13$ j 8 to 12 in. S. $\quad 125$ 2 to $3 \mathrm{ft}$. S. $\quad 150$ 18 to 24 in. tr. $\quad 125$ $3 \mathrm{ft}$. tr. $\quad 150$ 10 to $15 \mathrm{in.S.} \quad 100$ 4 to $5 \mathrm{ft}$. tr. $\quad 150$ 3 to $4 \mathrm{ft}$. tr. $\quad 250$ 2 to $3 \mathrm{ft}$. 175 2 to 18 in. tr. 200 3 to $4 \mathrm{ft}$. $\quad 200$

$2 \mathrm{ft} . \mathrm{tr} . \quad 125$

1 to $2 \mathrm{ft}$. tr. $\quad 150$

1 to $2 \mathrm{ft}$. tr. $\quad 85$

$5 \mathrm{ft}$. C. $\quad 125$

18 to 21 in. S. 150

2 to $3 \mathrm{ft} . \mathrm{S}, \quad 200$

$2 \mathrm{ft}$. C. $\quad 150$

6 in. S. $\quad 50$

10 to 15 in. S. $\quad 100$

$2 \mathrm{ft} . \mathrm{S}$. $\quad 125$

6 to 10 in. S. $\quad 75$

10 to 12 in. tr. 100

$2 \mathrm{ft} . \mathrm{tr}$ I 50

12 to 18 in. tr. $\quad 150$

2 to $3 \mathrm{ft}$. tr. $\quad 300$

5 to 6 in. $s . \quad 50$

12 to 18 in. tr. $\quad 85$

4 to $5 \mathrm{ft}$. tr. I 25

18 to 24 in. S. $\quad 100$

6 to 8 in. tr. $\quad 125$

18 to 24 in. tr. 250

12 to $15 \mathrm{in.}$ tr. 250

12 to $18 \mathrm{in.} \mathrm{tr.} 250$

5 to 6 in.' $\mathrm{S}$. $\quad 50$

$1 \mathrm{ft}$. $\quad 150$

$2 \mathrm{ft} . \quad 250$

18 to 24 in. $\quad 100$

3 to $4 \mathrm{ft} . \mathrm{tr}, \quad 150$

18 to 24 in. C. $\quad 75$

$3 \mathrm{ft} . \mathrm{tr} . \quad 100$

$5 \mathrm{ft} . \mathrm{tr}$. 12.

18 to 24 in. C. $\quad 100$ 3 to $4 \mathrm{ft}$.tr. 125

600

1200

1500

1800

1000

500

800

1000

1200

400

700

1n 00

2000

400

600

12 to $15 \mathrm{in.} \mathrm{tr} . \quad 100 \quad 800$

18 to 24 in. C. $\quad 75 \quad 500$
1200

2000 


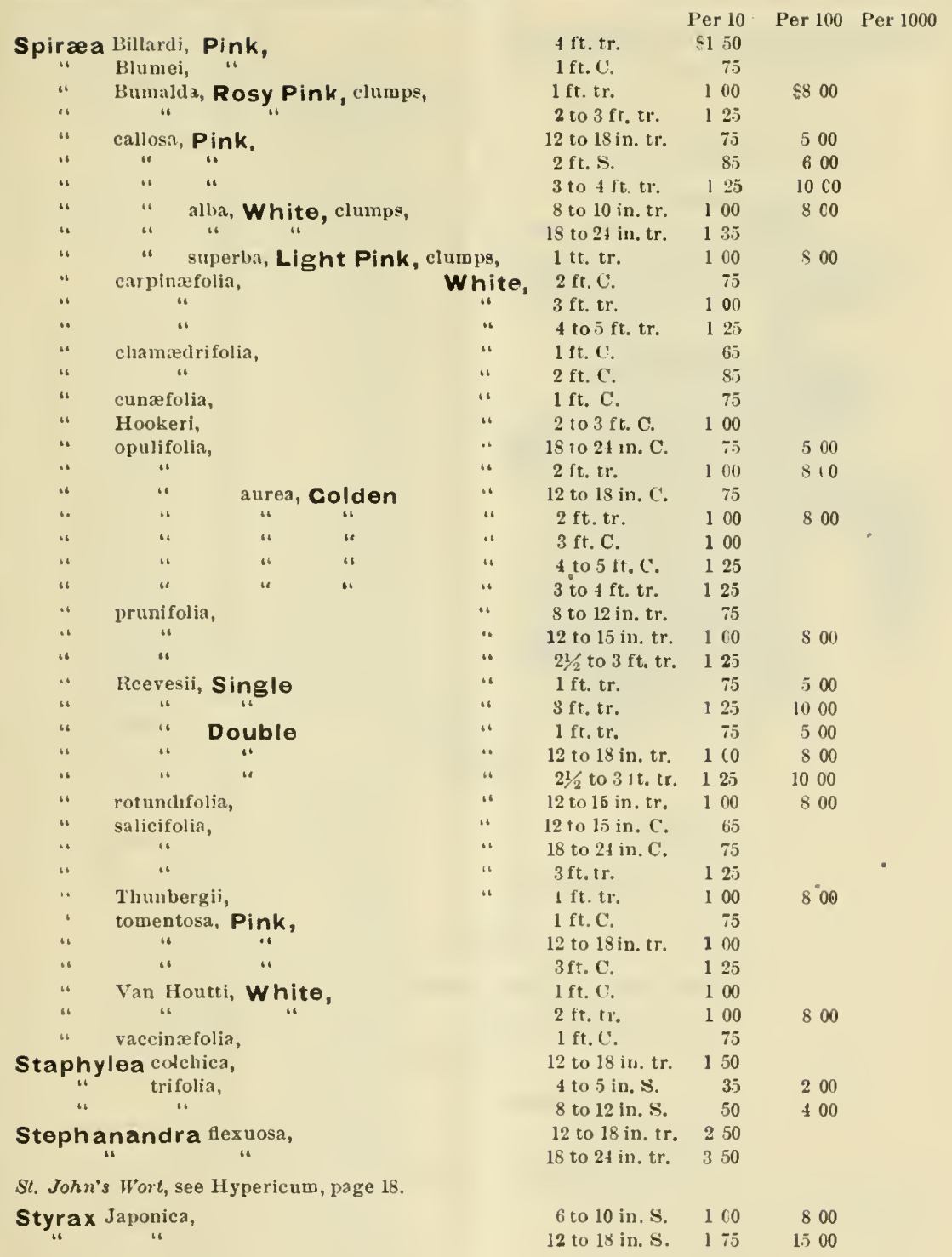

Sumach, see Rhus, page 20.

Sweet Brier, see Rosa, page 20.

Sweet Fern, see Comptonia, page 16.

Sueel Shrub, see Calycanthus, page 15.

Symphoricarpus racemosus,

\begin{tabular}{|c|c|c|c|c|c|}
\hline & White Sno & wborry, & 12 to 18 in. $\mathrm{C}$. & 100 & \\
\hline " & " & $"$ & 13 to $21 \mathrm{in.} \mathrm{tr}$. & 125 & 1000 \\
\hline “" & “" & 16 & $2 \mathrm{it}$ & 150 & 1200 \\
\hline ulgaris, & Red & 4 & $18 \mathrm{tn} 2 \mathrm{fin}, \mathrm{tr}$ & 100 & 800 \\
\hline 16 & " & $"$ & $21 / 2$ to $3 \mathrm{ft}$. tr. & 125 & 1000 \\
\hline " & variegated & $"$ & 12 to 18 in. $\mathrm{C}$. & 100 & \\
\hline
\end{tabular}




\begin{tabular}{|c|c|c|c|c|c|c|}
\hline \multirow{3}{*}{ Syringa } & & \multicolumn{2}{|r|}{ Per 10} & \multirow[t]{2}{*}{ Per 100} & \multirow[t]{2}{*}{ Per 1000} \\
\hline & Amurense & , Amoor White Lilac, & 2 ft. tr. & $\$ 125$ & & \\
\hline & Emodi, & & 12 to 18 in. tr. & & & \\
\hline " & " & & 18 to 24 in. tr. & 100 & $\$ 800$ & \\
\hline “" & Japonica, & "6 & 18 to 24 in. tr. & 150 & & \\
\hline " & " & & 2 to $21 / 2 \mathrm{ft}$. tr. & 200 & & \\
\hline " & Josekæ, P & urple, Late, & 12 to 18 in. tr. & 75 & 500 & \\
\hline ‘. & " & & 18 to 24 in. tr. & 100 & 800 & \\
\hline “ & ligustrina, & White, & 2 to $3 \mathrm{ft}$. tr. & 125 & 1000 & \\
\hline 4 & 16 & pendula, Wooping. & 6 to $8 \mathrm{ft} . \mathrm{tr}$ & 400 & & \\
\hline " & oblata, & Purple, & 18 to 24 in. tr. & 150 & & \\
\hline “" & Persica, $P$ & ersian & $1 \mathrm{ft} . \mathrm{C}$. & 50 & 300 & \\
\hline “" & " & " & 12 to 18 in. $\mathrm{C}$. & 75 & 500 & \\
\hline " & $"$ " & " & 18 to 24 in. tr. & 100 & & \\
\hline "“ & “ & " & $3 \mathrm{ft} . \mathrm{tr}$ & 125 & & \\
\hline "، & $"$ " & ersian White, & 6 in. & 75 & & \\
\hline " & “ & & 18 to $24 \mathrm{in.tr}$. & 100 & & \\
\hline " & $"$ & " & $2 \mathrm{ft} . \mathrm{tr}$. & 125 & & \\
\hline " & Rothmage & ensis, Purple, & lft. tr. & 75 & 500 & \\
\hline " & “ & & 2 ft. tr. & 100 & 800 & \\
\hline " & " & & s ft. tr. & 125 & 1000 & \\
\hline " & vulgaris, $\mathrm{C}$ & Cominon Purple, & 6 in. $\mathrm{s}$. & 30 & & \\
\hline “ & 16 & “r & 12 to 18 in. $\mathrm{s}$. & 40 & 300 & \\
\hline "، & “ & “ & 18 to 24 in. $\mathrm{S}$. & 75 & & \\
\hline " & "6 & $\cdot$ & 18 to $24 \mathrm{in.tr}$. & 85 & 700 & \\
\hline " & "، & & 2 to $3 \mathrm{ft}$. tr. & 100 & 800 & \\
\hline ". & "6 & & 3 to $4 \mathrm{ft}$. tr. & 150 & 1200 & \\
\hline$\because$ & “ & alba, Common White, & 12 to 18 in. tr. & 40 & 300 & \\
\hline “" & “ & "4 & 18 to 24 in. $\mathrm{tr}$. & 75 & 600 & \\
\hline " & ": & “ & $21 / 2$ to $3 \mathrm{ft}$. tr. & 100 & 800 & \\
\hline " & " & "4 & 3 to $4 \mathrm{ft}$. tr. & 150 & 1200 & \\
\hline " & $" 1$ & Ambroise Verschaffelt, Light & & & & \\
\hline & & Purple, & 12 to 18 in. tr. & 75 & & \\
\hline “" & "6 & (1) & 2 to $2 \frac{1}{2} \mathrm{ft} . \mathrm{tr}$. & 125 & & \\
\hline " & " & Amethyste, & 18 to 24 in. tr. & 150 & & \\
\hline 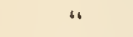 & ' & Charles $\mathrm{X}$. & 18 to 21 in. tr. & 100 & & \\
\hline 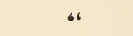 & " & 6 & 2 to $2 \frac{1}{2} \mathrm{ft}$. $\mathrm{tr}$. & 125 & & \\
\hline “ & “ & Dr. Stockhardt, White, & 12 to $1 \mathrm{sin}$. tr. & 75 & & \\
\hline “ & “. & " & $2 \mathrm{ft} . \mathrm{tr}$ & 125 & & \\
\hline "“ & : & Gloire de Moulins, Purple, & 12 to 18 in. tr. & 75 & & \\
\hline " & “ & " & 18 to 24 in. $\mathrm{tr}$. & 100 & & \\
\hline “" & ‘. & Marie Legray, White Dwarf, & 12 to 18 in. $t r$. & 100 & 800 & \\
\hline " &. & " & 18 to 24 in. tr. & 125 & 1000 & \\
\hline “ & "6 & plena, Double Purple, & 12 to $18 \mathrm{in.} \mathrm{tr}$ & 75 & & \\
\hline “. & "* & a. & 18 to $2 \mathrm{fin}$. tr. & 100 & 800 & \\
\hline "، & ". & " & 2 to $21 / 2 \mathrm{ft} . \mathrm{tr}$. & 125 & & \\
\hline “" & “ & Princess Marie, Purple, & 18 to 24 in. tr. & 100 & & \\
\hline " &. & " & 2 to $21 / 2 \mathrm{ft} . \mathrm{tr}$. & 125 & & \\
\hline ،. & “ & Professer Sargent, & 12 to 18 in.tr. & 100 & & \\
\hline " & $"$ " & rubra de Morley, Rөd, & 18 to 24 in. tr. & 100 & 800 & \\
\hline " & " & " insignis, " & 12 to $18 \mathrm{in.} \mathrm{tr}$. & 75 & 500 & \\
\hline "، & "، & " 4 & 18 to $21 \mathrm{in.} \mathrm{tr}$. & 100 & 800 & \\
\hline " & c. & " " & 2 to $21 / 2 \mathrm{tt}, \mathrm{tr}$. & 125 & & \\
\hline “ & " & rubella fl. pl., & 18 to $24 \mathrm{in}, \mathrm{tr}$. & 125 & & \\
\hline s. & "، & Senator Vollard, & 18 to 24 in. $\mathrm{tr}$. & 125 & & \\
\hline “ & “ & villosa, Light Purple Late, & 18 to $24 \mathrm{in.} \mathrm{tr}$. & 100 & & \\
\hline$: 4$ & " & " & 2 to $21 / 2 \mathrm{ft}$. tr. & 125 & & \\
\hline
\end{tabular}

Our collection of Lilacs is exceptionally fine, many of the sorts offered baving been but recently introduced.

Tamarix Gallica,

" $\quad$ Indica,
Indaponica,
tetranda,

18 to 24 in. U. 125 3 to $4 \mathrm{ft}$. $\quad 150$ 18 to 24 in. C. 125 18 to 21 in. C. 100 
Tamarix tetranda,

Vaccinium corymbosum, Blueberry, .. Pennsylvanicum, Huckleberry, vacillans,

\begin{tabular}{|c|c|c|}
\hline & Per 10 & Per 100 \\
\hline 3 to $4 \mathrm{ft}$. tr. & $\$ 125$ & $\$ 1000$ \\
\hline 4 to $5 \mathrm{ft} . \mathrm{tr}$. & 150 & 1200 \\
\hline 8 to 12 in. $t r$. & 125 & \\
\hline 8 to $12 \mathrm{in}, \mathrm{tr}$. & 125 & \\
\hline 8 to $12 \mathrm{in} . \mathrm{tr}$. & 125 & \\
\hline
\end{tabular}

JAPAN SNOWBALL - Viburnum plicatum.

This electrotype given to purchascrs of plants on application.

When we first commenced growing this plant, our sales of it were but a hundred or two a year; but it is now so popular that though we are growing it by the thousands, we have scarcely enough to supply all orders. Some idea may be had of the great quantities we are now growing, when we say that we could supply fifty tlousand plants of various sizes at this writing. Every nurseryman and dealer should handle it.

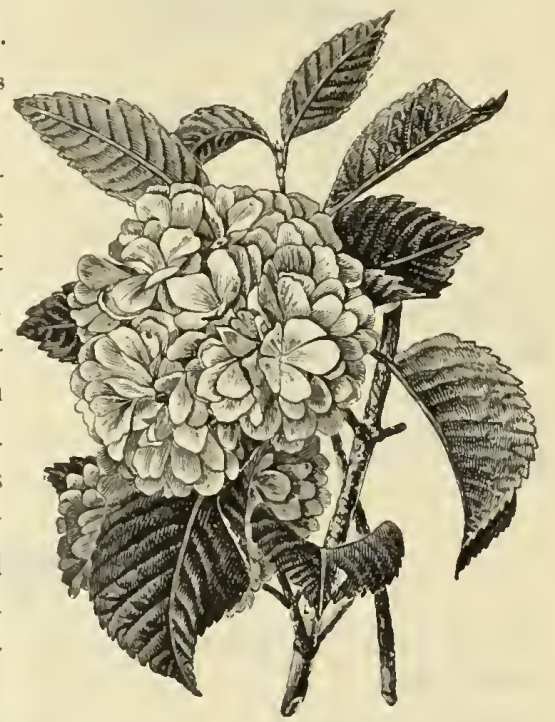

\section{Viburnum acerifolium,}

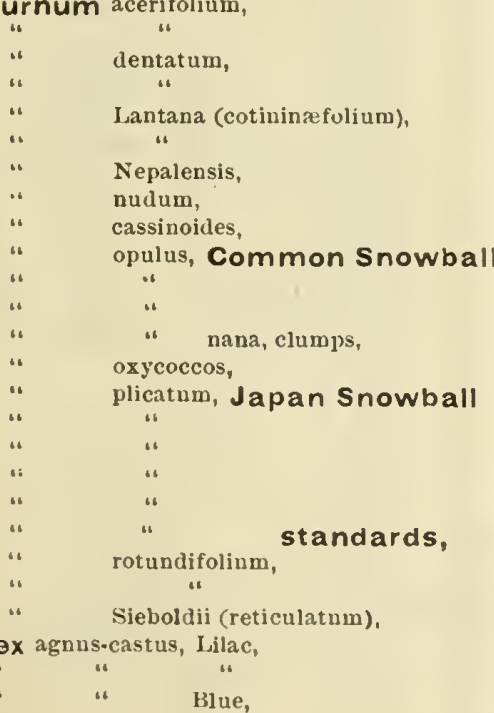

Wax Myrtle, see Myrica, page 19.

Weigela amabilis, Llght Rose,

\begin{tabular}{|c|c|c|c|}
\hline 12 to $18 \mathrm{in} . \mathrm{tr}$. & 150 & & \\
\hline 18 to 24 in. $\mathrm{tr}$. & 175 & & \\
\hline 18 to $21 \mathrm{in.} \mathrm{tr}$. & 200 & & \\
\hline $2 \mathrm{ft} . \mathrm{tr}$ & 250 & & \\
\hline 4 to 5 in. $\mathrm{S}$. & 75 & & \\
\hline 2 to $3 \mathrm{ft} . \mathrm{S}$. & $2 \mathrm{CO}$ & & \\
\hline 12 to 15 in $\mathrm{tr}$. & 150 & & \\
\hline 12 to 18 in. tr. & 150 & & \\
\hline 8 to 12 in. tr. & 125 & & \\
\hline 12 to $15 \mathrm{in}, \mathrm{tr}$. & 100 & 800 & \\
\hline 18 to 24 in. $t r$. & 125 & 1000 & \\
\hline $21 / 2$ to $3 \mathrm{ft}$. $\mathrm{tr}$. & 150 & & \\
\hline 8 to 10 in. tr. & 100 & & \\
\hline 8 to 12 in. $t r$. & 175 & & \\
\hline 12 to 18 in. tr. & 200 & 1800 & \\
\hline $21 / 2$ to $3 \mathrm{ft}$. tr. & 250 & 2500 & $\$ 25000$ \\
\hline 3 to $4 \mathrm{ft}$. tr. & 300 & 3000 & 30000 \\
\hline 4 to $5 \mathrm{ft}$. tr. & 350 & $35 \mathrm{CO}$ & 35000 \\
\hline $6 \mathrm{fr} . \mathrm{tr}$. & 400 & & \\
\hline 4 to $5 \mathrm{ft}$. tr. & 350 & $3 j 60$ & \\
\hline 12 to 18 in. $t r$. & 250 & & \\
\hline 3 to $4 \mathrm{ft} . \mathrm{tr}$. & 300 & & \\
\hline 12 to 18 in. tr. & 250 & & \\
\hline $6 \mathrm{in.} . \mathrm{S}$. & 75 & 500 & \\
\hline 12 to 18 in. $s$. & 100 & & \\
\hline 12 to 18 in. C. & 150 & & \\
\hline 18 to 24 in. $\mathrm{C}$. & 75 & 600 & \\
\hline $21 / 2$ to $3 \mathrm{ft}$. tr. & 125 & & \\
\hline
\end{tabular}


Weigela arborea "versícolor, Dark Rose,

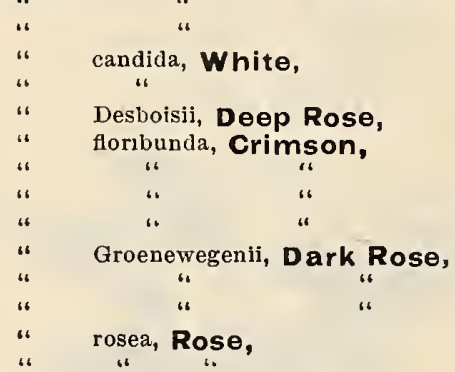

White Fringe, see Chionanthus, page 15.

Witch Hazel, see Hamamelis, page 17.

Xanthoceras sorbifolia,

"،

Zanthorhiza apifolia,

Zizyphus vulgaris,
Per 10

1 ft. tr. $\quad \$ 075$

2 to $3 \mathrm{ft}$. tr. $\quad 100$

3 to $4 \mathrm{ft}$. tr. $\quad 125$

18 to 24 in. C. $\quad 85$

$2 \mathrm{ft}$. tr. 100

$3 \mathrm{ft} . \mathrm{tr} . \quad 125$

1 ft. tr. $\quad 75$

18 to 24 in. tr. 85

$2 \mathrm{ft}$ tr. $\quad 100$

$21 / 2$ to $3 \mathrm{ft} . \mathrm{tr} . \quad 125$

12 to 18 in. C. 75

18 to $2 t$ in. C. 85

$4 \mathrm{ft}$. tr. $\quad 125$

$1 \mathrm{ft}$. tr. $\quad 75$

$3 \mathrm{ft} . \mathrm{tr} . \quad 125$
Per 100 Per 1000

$\$ 800$

700

600
12 to 18 in. tr. 150

18 to 21 in. $t r .200$

2 to $3 \mathrm{ft}, \mathrm{tr} . \quad 300$

1 ft. $t$. $\quad 300$

8 to 12 in. S. 150

\section{Evergreens.}

The letter " $\mathrm{S}$ " indicates seedlings. All other stock has been once or more transplanted.

$\begin{array}{ccc}\text { Abies alba, White } \\ \text { " } & \text { " } & \\ \text { " } & \text { Canadensis, Hemlock } \\ \text { " } & \text { " } & \text { " } \\ \text { " } & \text { Douglasii, Douglas } \\ \text { " } & \text { " } \\ \text { " } & \text { excelsa, Norway } \\ \text { " } & \text { " } & \text { " } \\ \text { " } & \text { " } & \text { " } \\ \text { " } & \text { " } & \text { " } \\ \text { " } & \text { " Weeping Norway } \\ \text { " } & \text { Orientalis, Oriental }\end{array}$

Andromeda calyculata,

" floribunda,

Japonica,

\begin{tabular}{|c|c|c|c|c|}
\hline Spruce, & 5 to 6 iu. & $\begin{array}{c}\text { Per } 10 \\
\$ 050\end{array}$ & $\begin{array}{r}\text { Per } 100 \\
\$ 400\end{array}$ & Fer 1000 \\
\hline 4 & 8 to 12 in. & 75 & & \\
\hline & 6 to $8 \mathrm{in}$. & 50 & 400 & \\
\hline " & 8 to 12 in. & 100 & & \\
\hline ، & 18 to 24 in. & 150 & 1200 & \\
\hline “ & 2 to $3 \mathrm{ft}$. & 360 & 2500 & \\
\hline " & 6 to $8 \mathrm{in}$. & 75 & 500 & \\
\hline “ & 12 to 15 in. & 150 & 1200 & \\
\hline “ & 8 to 12 in. $S$. & 40 & 250 & $\$ 1000$ \\
\hline " & 18 to 24 in. $S$. & 60 & 350 & 1500 \\
\hline “" & 18 to 24 in. & 75 & 500 & 3000 \\
\hline "1 & 2 to $21 / 2 \mathrm{ft}$. heavy & у 125 & 1000 & 6000 \\
\hline “. & $21 / 2$ to $3 \mathrm{ft}$. heavy & $\begin{array}{lll}y & 75 \\
0\end{array}$ & 1500 & 12000 \\
\hline "، & 3 to $4 \mathrm{ft}$, heavy, & 300 & 2500 & 20000 \\
\hline " & 5 to $7 \mathrm{ft}$. heavy & 500 & 4000 & \\
\hline
\end{tabular}

400

800

1200

$6 \mathrm{in}$.

200

$"$

6 to 8 in.

15 in.

150

Arctostaphylos uva-ursi,

Biota Orientalis,

\section{Chines}

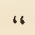

"aurea

" "Roilinsons" " " "

" $2 \mathrm{ft}$.

250

$3 \mathrm{ft} . \quad 350$

Buxus sempervirens, Box-edging, per yard 25 ccnts.
" rotundifolia,
8 to 12 in. $\quad 100$
S to 10 in. $\quad 250$

Calluna vulgaris, 
Cedrus Deodaı, libani,

Cephalotaxus Fortnni,

Cryptomeria Japonica,

$$
\text { " " compacta, }
$$

Cunninghamia lenccolata,

Cupressus Lawsoniana, Lawson's Cypress,

$\begin{array}{ll}" \text { " } & \text { "lutescens, Colden " } \\ " & \text { "strleta viridis. }\end{array}$

Daphne cheorum,

Ericavagans capitata,

Euonymus Japonlcus,

Fir, see Picea, below.

Hemlock, see A bies, paze 24.

Holly, see llex, below.

Ilex opaca, Am. Holly,

Japan Cedar, sce Retinospora, page 26.

Juniperus Chinensis, Chinese Juniper,

communis, Common "
Hibernica, Irish ".
"Sabina, Savin,
stricta, (dwarf, compaci, bushy),

Kalmia angustifolia, Laurel,

$$
\text { " latifolia, " }
$$

Mahonia aıuifolia,

$$
\text { Japonica, }
$$

Norway Spruce, see Abics, page 24.

Picea lalsamea, Balsam Fir,

$$
\begin{aligned}
& \begin{array}{lll} 
& \text { " } &
\end{array} \\
& \text { " Nordmanniana, }
\end{aligned}
$$

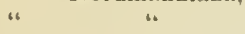

$$
\begin{aligned}
& \text { “ pectinata, Silver Fir, }
\end{aligned}
$$

Pinus Austriaca, Austrian Pine,

Banksiana,

densiflora, Japan,

Ma‘soniana,

ponderosa,

rigida, Pitch

strobus, White

\begin{tabular}{|c|c|}
\hline $3 \mathrm{ft}$ & $\$ 100$ \\
\hline 2 to $3 \mathrm{ft}$. & 400 \\
\hline $3 \mathrm{ft}$ & 750 \\
\hline 6 to $8 \mathrm{in}$. & 100 \\
\hline 6 to $8 \mathrm{in.}$ & 15 \\
\hline $5 \mathrm{in.}$ & 30 \\
\hline 6 to 8 in. & 10 \\
\hline 8 to $12 \mathrm{in}$. & 150 \\
\hline$I \mathrm{ft}$. & 150 \\
\hline 6 to $8 \mathrm{in}$. & 15 \\
\hline 8 to 12 in. & 1 \\
\hline 12 to 18 in. & 1 \\
\hline 8 to 12 in. & 2 \\
\hline 6 to 8 in. & 2 \\
\hline 6 in & \\
\hline to $18 \mathrm{iu}$. & \\
\hline
\end{tabular}

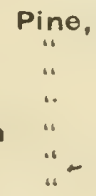

Prinos giaber, Ink Berry,

Rhododendron, assorted,

Catawbiense, scedlings,
Per 100 Per 1000

$\$ 800$

1000

1200

3 to 5 in. $s$.

75

12 to 18 in.

200

18 to $24 \mathrm{in.} \quad 150$

3 to $4 \mathrm{ft}$. 250

$2 \mathrm{ft} . \quad 150$

6 in. 6.5

18 to 24 in. $\quad 150$

5 ill. 75

12 to 18 i1. 150

6 to 8 in. $\quad 75$

$1 \mathrm{ft} . \quad 100$

8 ti) $12 \mathrm{in.} \quad 200$

8 to $10 \mathrm{in.} \quad 250$.

12 to 1 s in. $\quad 350$

12 to $18 \mathrm{ill} . \quad 150 \quad 1000$

6 to $10 \mathrm{in.} \quad 100 \quad 800$

6 to 8 in. $\quad 50 \quad 400$

18 to $21 \mathrm{in.} \quad 100 \quad 800$

$2 \mathrm{ft}$. $\quad 1.50$

$4105 \mathrm{ft}$. $\quad 350$

6 in. $\quad 150$

8 to 10 in. $\quad 200$

$6 \mathrm{in.} \quad 50$

8 to 12 in. $\$$. 35

6 to 8 in. $\quad 50$

8 to 10 in. 75

Is to $21 \mathrm{in.} \quad 100$

18 to 24 in. S. 100

2 to $3 \mathrm{fc} . \quad 200$

2 to $3 \mathrm{ft}$. s. $\quad 150$

6 to $b$ in. $\quad 100$

12 to $15 \mathrm{in.} \mathrm{S} . \quad 75$

6 to 8 in. S. $\quad 40$

12 to 15 in. $\quad 100$

2 to $3 \mathrm{ft}$. 200

12 to 15 in. $S$. $\quad 50$

8 to 10 in. $\quad 75$

12 to $15 \mathrm{in.} \quad 100$

I $\mathrm{ft}$. 250

15 in. bushy 750

15 to 21 in. bushy 600
600 
Retinospora ericoides, filifera, leptoclada,

plumosa,

16

6

" aurea, Colden,$$
\text { " }
$$

obtusa compacta, Clobe, "

"

pisifera aurea,

" "

4

Sielboldi,

squarrosa,

Scotch Heath, see Calluna, page 24.

Spruce, see A bies, page 21 .

Taxus baccata, English $Y$ ew,

"Canadensis, Am.

Thuja Geo. Peabody, Golden Arbor Vitæ,

" ericoides, Heath Leaved"

tilifin Lea th Leav"

" tilifolia, Fern Leaved .".

" globosa, Clobe "“

" " " " "

" " " " "

" " " " " " "

Hoveri, Hovey's

"Little Gem, Dwarf

"Meehani, Colden

" occidentals, Am.

". "

16 6 6

4

"4

pumila, Globe

Sibirica, Siberian

6

spiralis,

Tom Thumb,

Victoria, Silver Tipped "“

Ulex Europæa, Furze,

Yew, see Taxu :, above.

Yucca angustifolia,

“ filamentosa

Per 10

6 in. bushy $\$ 75$

6 in. $\quad 75$

$1 \mathrm{ft.} \quad 100$

19 to 24 in. $\quad 250$

6 to $10 \mathrm{in.} \quad 65$

12 to 18 in. $\quad 125$

18 to 24 in. $\quad 150$

6 to 8 in. $\quad 75$

8 to 12 in. $\quad 125$

6 in. $\quad 125$

8 to 12 in. $\quad 175$

12 to 15 in. $\quad 250$

6 to 8 in. $\quad 75$

12 to 18 in. $\quad 150$

18 to 24 in. $\quad 250$

12 to 18 in. bushy 150

$5 \mathrm{in.}$

65

8 to 12 in. $\quad 100$

ј 00

10 to 12 in. $\quad 150$

2 to $3 \mathrm{ft}$. $\quad 300$

5 to 6 in. $\quad 100$

18 to 24 in. bushy 150

8 to 12 in. $\quad 100$

12 to 18 in. $\quad 150$

6 in. bushy 75

8 to 12 in. busks 100

$1 \mathrm{fc}$. 150

$18 \mathrm{in.}$ very beavy 300

8 to 12 in. buslny 125

6 in. $\quad 150$

8 to 10 in. $\quad 125$

8 to 12 in. 50

$2 \mathrm{ft} . \quad 100$

2 to $3 \mathrm{ft}$. $\quad 125$

3 to $4 \mathrm{ft} . \quad 175$

4 to $5 \mathrm{ft} . \quad 225$

8 to 12 in. $\quad 100$

5 in. 75

2 to $3 \mathrm{ft} . \quad 250$

12 to $15 \mathrm{in.} \quad 150$

6 in. bushy 75

12 to $15 \mathrm{in.} \quad 150$

18 to $21 \mathrm{in.} \quad 300$

18 to 21 in. S. $\quad 100$

$300 \$ 2500$

700

1100

1500

2000

500

9000

12500

Arbor Vitce, see Thuja occidentalis, above.

Beech, American, see Fagus Americana, page 6.

Buckthorn, see Rhamnus catharticus, page 20.

Hardy Orange, see Citrus trifoliata, page 15.

Hemlock, see Abies Canadensis, page 21.

Norway Spruce, see Abies excelsa, page 24.

Privet, Californian, see Ligustrum, page 18.

Pyrus Japonica, (Cydonia), see page 19.

$\begin{array}{lr}1 \text { year } \mathrm{S} . & 75 \\ \text { 1 yeais tr. } & 250 \\ 2 \text { years } \mathrm{S} . & 150\end{array}$

2 years tr. 250

\section{Hedge Plants.}




\section{Vines and Climbers.}

Actinidia polygama,

Ampolopsis dissecta,

".
". Vipinnata,
"Virginica, Japan Ivy,

Bignonia capreolata,

". grandiflora, Chinese Trumpet VIne,
radicans, Am.

" Thunbergii, Crimson

Celastrus articulata, Staff Vino,<smiles>[Mg][Ge]#[Ge]</smiles>

Decumaria barbara

Dolichos Japonicus,

"" "

Euonymus radicans,

$$
\text { ". " " variegata, }
$$

Celsimium sempervirens,

Jasminum nudiflorum, Yellow Jasmine,

$$
\begin{array}{lll}
" \text { " } & \\
" \text { " } & \\
\text { " } & \text { officinale, Whito }
\end{array}
$$

Lonicera Belgica, Monthly

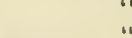

Honeysuckle,
18 to 24 in. $\$ 300$

2 to $3 \mathrm{ft} . \quad 150$

12 to $18 \mathrm{in.} \quad 100$

2 to $3 \mathrm{ft} . \quad 150$

1 to $2 \mathrm{ft}$. 75

6 to $10 \mathrm{in.} \quad 35$

1 to $2 \mathrm{ft}$. 75

10 to $15 \mathrm{in.} \quad 200$

$2 \mathrm{ft} \quad 200$

8 to 12 in. $\quad 100$

2 to $3 \mathrm{ft}, \quad 150$

2 to $3 \mathrm{ft} . \quad 200$

12 to 18 in. $\quad 150$

2 to $3 \mathrm{ft} . \quad 2 \mathrm{no}$

6 to $10 \mathrm{in} . \quad 100$

2 to $3 \mathrm{ft}$. $\quad 150$

$1 \mathrm{ft} .15$

1 jear 150

2 years $2(0$

8 to 12 in. $\quad 100$

12 to 18 in. $\quad 150$

6 to $\mathrm{Sin}$. $\quad 10$ s

12 to $18 \mathrm{in.} \quad 150$

$1 \mathrm{ft} . \quad 150$

$1 \mathrm{ft}$

$2 \mathrm{ft} . \quad 125$

$3 \mathrm{ft} . \quad 150$

18 to 24 in. $\quad 150$

2 to $3 \mathrm{ft} . \quad 175$

175
100

150

7.5

100

100

150

150

150

150

100

150

100

150

100

200

12 to 18 in.

$2 \mathrm{ft}$.

1 s to 24 in. $\quad 125$

2 to $3 \mathrm{ft}$. $\quad 200$

3 to $f \mathrm{ft}$. 250

6 to $10 \mathrm{in.} \quad 7.5$

2 to $3 \mathrm{ft} . \quad 150$

6 in. $\quad 150$

$1 \mathrm{ft} . \quad 200$

18 to $2 t \mathrm{in.} \quad 250$

12 to 15 in. $\quad 250$

3 to $5 \mathrm{in}$.

6 to 8 in.

1s to 24 in.

6 to $\mathrm{sin}$.

6 to 8 in.
Per 100 Per 1000

$\$ 1200$

500

300

500

$\$ 2000$

1500

2000

800

1000

810

1200

800

800

800

1000

1000

800

1600

500

2000

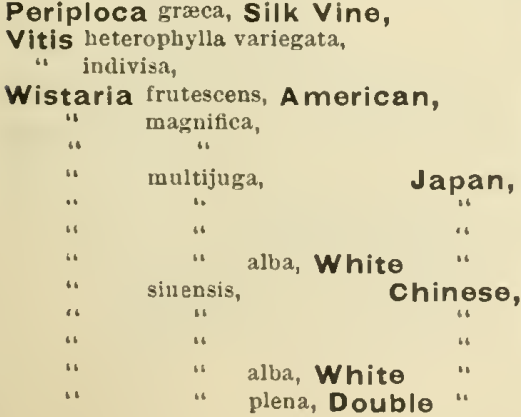

alba, White

" $"$ plena, Double

\section{Chinese,}

"6

Periploca græca, Silk Vin

Wistaria frutescens, American, 


\section{Tree and Fruit Seeds.}

\section{EVERGREENS.}

A bies alba, White

" Canadensis, Hemlock

" Douglasii, Douglas excelsa, Norway

Juniperus Virginiana, Red Cedar,

Mahonia aquifolia,

Magnolia grandiflora,

Picea balsamea, Balsam

"Nordmanniana, Nordman's pectinata, European Silver

Pinus Austriaca, Austrian

" cembra, Swiss

" excelsa, Himalayan

Laricio, Corsican

mitis,

montana, Mountain

rigida, Pitch

strobus, White

sylvestris, Scotch

T axus baccata, English

Canadensis, American

Spruce,
“
(the hardy sort)

\begin{tabular}{|c|c|}
\hline Per lb. & Per oz \\
\hline$\$ 175$ & $\$ 50$ \\
\hline 450 & 40 \\
\hline 550 & 60 \\
\hline 85 & 20 \\
\hline 75 & 15 \\
\hline 500 & 50 \\
\hline 225 & 25 \\
\hline 150 & 20 \\
\hline 400 & 40 \\
\hline 100 & 20 \\
\hline 100 & 15 \\
\hline 100 & 15 \\
\hline & 125 \\
\hline 250 & 25 \\
\hline & 75 \\
\hline 300 & 30 \\
\hline 400 & 40 \\
\hline 200 & 25 \\
\hline 150 & 20 \\
\hline 200 & 25 \\
\hline & 75 \\
\hline 300 & 30 \\
\hline 200 & 20 \\
\hline
\end{tabular}

Thuja occidentalis, American Arbor Vitæe,

\section{DECIDUOUS TREES AND SHRUBS.}

A cer campestre, English Cork

" platanoides, Norway

“ pseudo-platanus, Sycamore

‘ rubrum, Red

saccharinum, Sugar

Ailantus glandulosa, Ailanthus,

Alnus glutinosa, European Alder,

Amelanchier Botryapium, June Berry,

Anona triloba, Paw Paw,

Aralia spinosa,

Berberis vulgaris, Berberry.

purpurea, Berberry, Purple,

Betula alba, European White Birch,

$\begin{array}{ll}\text { " } & \text { excelsa, Yellow } \\ \text { " } & \text { papta, Sweet } \\ \text { " populifolid, Poplar } \\ \text { " rubra, Red }\end{array}$

Calycanthus floridus, Sweet Shrub,

Caragana arborescens

Carpinus Americana, American Hornbeam, Betulus, European

Carya alba, Sliellbark olivæformis, Pecan Hickory.

Per lb. Per oz.

$\$ 150 \leqslant 20$

$100 \quad 15$

$100 \quad 15$

200

$100 \quad 15$

$75 \quad 15$

150

150

100

250

$150 \quad 20$

$300 \quad 30$

$150 \quad 20$

150

$200 \quad 20$

$200 \quad 25$

$150 \quad 20$

$250 \quad 25$

110

$200 \quad 20$

$150 \quad 15$

$200 \quad 20$

"sulcata,

" tomentosa, White

Catalpa bignonioides, speciosa

Celtis occidentalis,

400 per buslicl, 
Cerasus Padus, European Bird Cherry,

Per 1b. Per oz.

"Cercis Canadeusis, America

Chlonanthus Virginica, White Fringe,

Cladastris tinctoria, Yellow Wood,

Cornus alternifolia, Blue Dogwood,

Cratagus cordata, Washington Thorn,

Cytisus Laburnum. oxycantlia, English Hawthorn,

Diospyros Virginiana, Perslmmon,

Fagus ferruginea, American Beech, sylvatica, European

Fraxlnus Americana, White Ash

$$
\begin{aligned}
& \text { " } \\
& \text { " quadrangulata, Blue } \\
& \text { sambucifolia, B!ack } \\
& \text { viridis, Green }
\end{aligned}
$$

Genista scoparius,

Cleditschia tracanthos, Honey Locust.

Cymnocladus Canadensis, Kentucky Coffoe

Halesia tetraptera, Snowdrop Tree,

Juglans cinerea, Butternut,

$$
\text { nigra, Black Walnut, }
$$

regia, English

Kolreuteria paniculata,

Larix Europien, European Larch,

Liquidambar styracitlua, Sweet Cum,

Liriodendron tulipifera, Tullp Tree,

Maclura aurantiaca, Osage Orange,

Magnolia acuminata,

$$
\begin{aligned}
& \text { glauca, } \\
& \text { macrophylla, } \\
& \text { tripetala, }
\end{aligned}
$$

Morus alba, White Mulberry,

Negundo fraxinafolium, Box Elder.

Nyssa inultitlora, Soul Gum,

Paulownia Imperialic, Empress Treo.

Philadelphus grandiflorus. W ock Orange,

Platanus occidentalis, American Plane,

$$
\text { orientalis, Oriental }
$$

Pyrus Amcricana, American Mountain Ash. aucuparia, European

Quercus alba, White Uak,

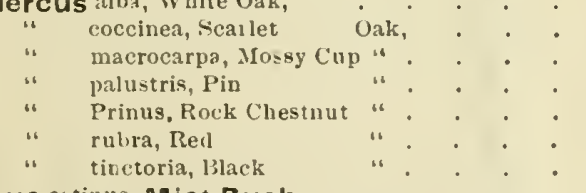

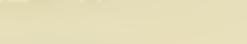

Taxodium distichum, Deciduous Cypress.

Tilla Americana, American Linden.

$$
\text { Europiea, European }
$$

Ulmus Americana, American EIm, 


\section{VINES AND CLIMBERS.}

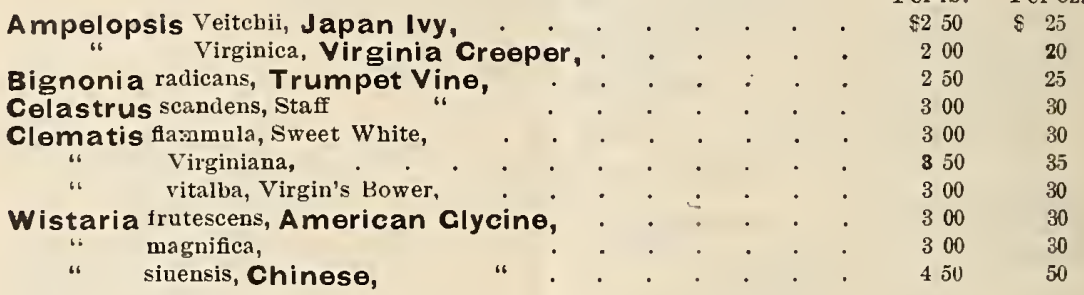

\section{FRUITS.}

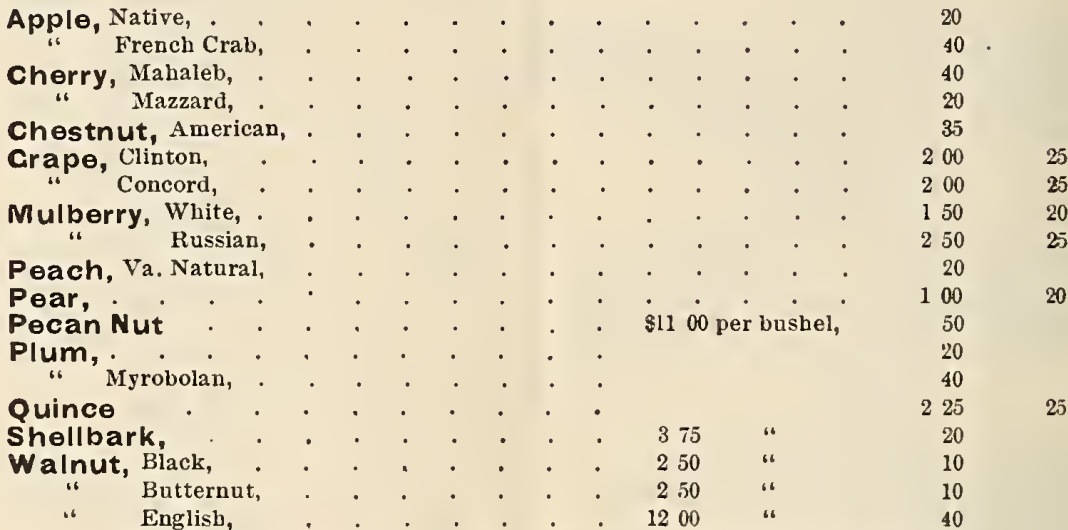

We can generally supply by the bushel, Apple, Cherry, Plum, Peach, Shellbarks, Walnuts, etc., and will give rates on application ; also Honey Locust and Osage Orange.

Our Retail Catalogue of Trees, Shrubs, etc., will be sent free to all applicants. 


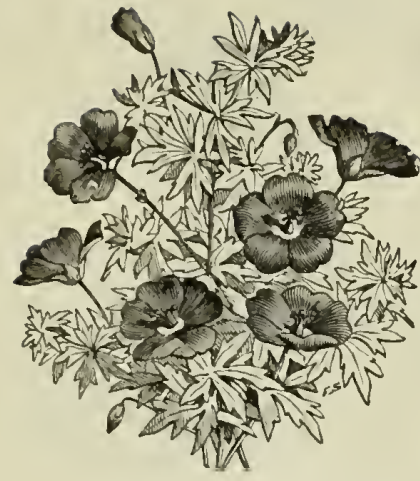

Geranium sanguineum.

\section{$H^{a r d y}$ \\ Perennials}

These plants have sprung into great prominence during the past few years, so that now no landscape work is deemed completed unless it embraces a number of these beautiful plants. - By careful serieties, it is have plants in early Spring to They require tention, and ing year adds of the plant, comes larger with age. - embraces all varieties usu-

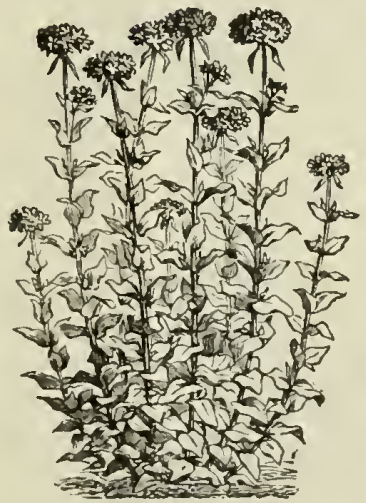

Lychnis chalcedonica.

lection of va possible to bloom from late Fall. - but little ateach succeedto the beauty as the root beand stronger Our collection the desirable ally offered for sale, as well as a great number not to be found in other nurseries. - - . - - For use in Parks and Cemeteries these plants are unexcelled; many spots now bare and without beauty can be made quite attractive. Descriptive Catalogue on application. - . - - -

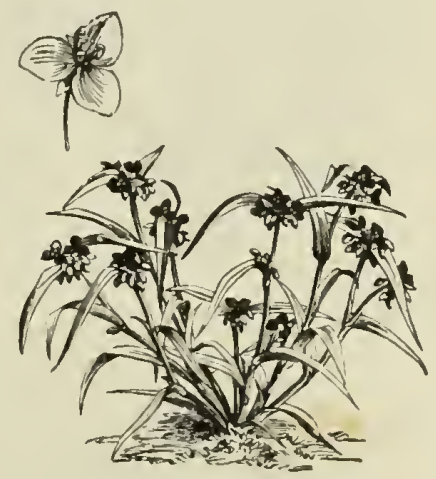

Tradescantia Virginica. 


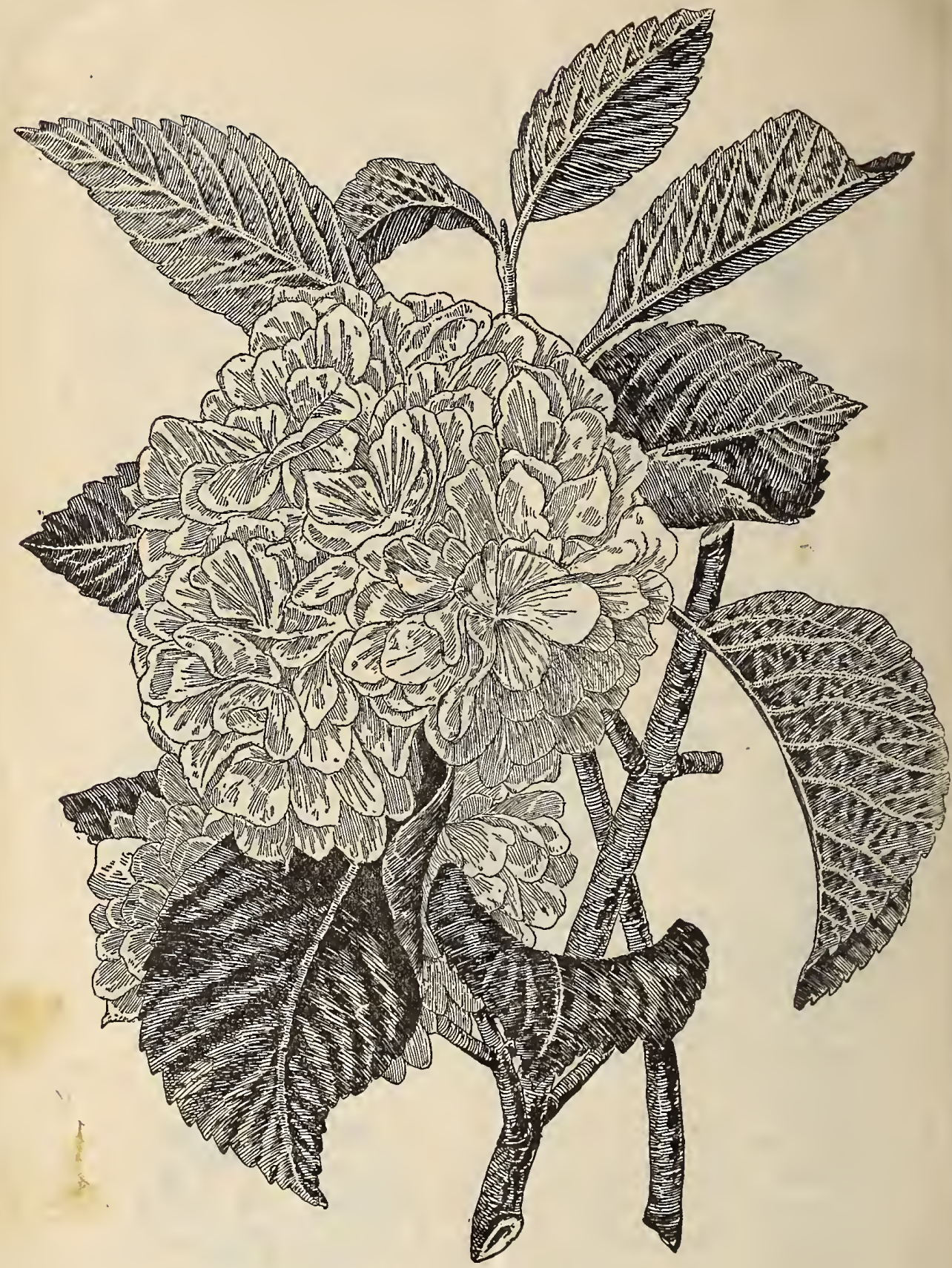

\section{JAPAN SNOWBALL}

(Viburnum plicatum)

A new variety of Snowball from Japan. Growth upright and compact. Foliage olive green through the summer, but toward fall it turns much darker and remains on the plant for some time after the first frosts. Flowers, though hardly as large as the old variety, are much more numerous. The leaves are in pairs along the stem, and from the base of each leaf a ball of flowers appears. There are often as many as ten pairs of these, or twenty balls, on a branch eighteen inches long. These balls, as they expand, all face upward, so that a full view of their great beauty is always to be had. To be a universal favorite a shrub must be hardy, easily transplanted and its growth of good shape, and beautiful both in leaf and flower, and the Japan Snowball embraces all of these points to the fullest extent. See page 23 .

We furnish the above electrotype to customers for 50 cents, postpaid. 